\title{
FERDO PAŽUR (1845. - 1911.). ZABORAVLJENI VARAŽDINSKI KLASIČNI FILOLOG I PREVODITELJ
}

Ferdo Pažur je klasični filolog, prevoditelj i pisac rodom iz Varaždina. Školovao se u varaždinskoj gimnaziji koju je završio 1862. godine kao najbolji učenik u razredu. U istoj je ustanovi zaposlen kao nastavnički pripravnik (suplent). Predavao je latinski, hrvatski i njemački jezik te zemljopis. Školovanje je nastavio na bečkome sveučilištu gdje je bio među najboljim studentima klasične filologije. Po povratku u domovinu radio je u varaždinskoj, požeškoj i osječkoj gimnaziji. Zbog ovisnosti o alkoholu, duševno je obolio. Živio je od prevođenja, pisanja i davanja instrukcija. Posljednje dane proveo je u varaždinskoj gradskoj ubožnici gdje je umro. Sahranjen je na gradskom groblju u Varaždinu. Ferdo Pažur ostavio je bogat opus sastavljen od prijevoda i izvornih djela. Ostalo je sačuvano više od trideset naslova Pažurovih prijevoda, većinom autora klasične grčke i rimske književnosti namijenjenih školskoj upotrebi, što mu je donijelo popularnost izvan domovine. Poznata su četiri Pažurova izvorna djela koja svjedoče o piščevom dubokom poznavanju hrvatskoga jezika i ljubavi prema hrvatskoj pisanoj riječi. lako zaboravljen, zahvaljujući svojem bogatom stvaralaštvu Ferdo Pažur zauzima značajno mjesto među varaždinskim prevoditeljima i jezikoslovcima. ${ }^{1}$

Ključne riječi: Ferdo Pažur; Varaždin; varaždinska gimnazija; klasična filologija; hrvatski jezik; prevođenje.

Rad je nastao na temelju istoimenog predavanja u organizaciji Hrvatske akademije znanosti i umjetnosti, Zavoda za znanstveni rad u Varaždinu i Gradske knjižnice i čitaonice "Metel Ožegović" Varaždin, koje je autorica održala 21. studenoga 2019. godine u Gradskoj knjižnici i čitaonici „Metel Ožegović“ Varaždin. 
ANA ŠKRILJEVEČKI: Ferdo Pažur (1845. - 1911.). Zaboravljeni varaždinski klasični filolog i prevoditelj

\section{ROĐENJE, OBITELJ I ŠKOLOVANJE}

Prema upisu u Maticu rođenih župe svetoga Vida u Varaždinu Ferdo Pažur rođen je 27. svibnja 1845. godine u Varaždinu. ${ }^{2}$ Puno ime mu glasi Ferdinand Mihael Pažur. Otac mu je bio Mihael (Mijo) Pažur, a majka Julijana Pažur rođena Gluhak. Od uže obitelji spominje se njegov brat Josip Pažur, nadarbenik (prebendar) Prvostolne crkve Zagrebačke nadbiskupije, koji je upravljao župom svete Marije na Dolcu u Zagrebu od 1893. godine. ${ }^{3} \mathrm{U}$ oporuci Ferdo Pažur kao svojeg baštinika navodi mlađega brata Vilibalda Pažura. ${ }^{4}$ Obitelj Pažur živjela je u Varaždinu gdje je Ferdo Pažur završio osnovnoškolsko obrazovanje. ${ }^{5}$ O njegovoj obitelji ne zna se puno, osim da mu je otac po zanimanju bio krojač. ${ }^{6} \mathrm{U}$ prvi razred varaždinske gimnazije upisan je školske godine 1854./1855. ${ }^{7} \mathrm{U}$ to je vrijeme obitelj Pažur živjela u Miličkoj ulici u Varaždinu, danas Ulici braće Radić. Ferdo Pažur isticao se među ostalim gimnazijskim učenicima. Hrvatski pedagog i učitelj Antun Cuvaj u svojem djelu Građa za povijest školstva kraljevina Hrvatske i Slavonije od najstarijih vremena do danas objavljuje svjedodžbu Ferde Pažura iz 1855. godine kao primjer gimnazijske školske svjedodžbe iz toga razdoblja. ${ }^{8}$ Svjedodžba pokazuje da je Ferdo Pažur bio odličan učenik te je po uspjehu bio prvi od ukupno 42 učenika. U Varaždinu je završio svih osam razreda gimnazije. ${ }^{9}$ Tijekom gimnazijskoga školovanja primao je stipendiju te nije trebao plaćati školarinu. U prvome polugodištu svoje posljednje školske godine Ferdo Pažur bio je najbolji učenik u razredu od ukupno 12 učenika, a u drugome polugodištu jedini od 10 učenika koji je dobio svjedodžbu prvoga reda s odlikom. ${ }^{10}$ Tijekom te posljednje godine

2 Državni arhiv u Varaždinu (dalje HR-DAVŽ). HR-DAVŽ 543. Matične knjige rimokatoličkih župa. Matica rođenih župe svetog Vida Varaždin (1831. - 1848.), zapis za 1845. godinu.

3 Ivan KAMPUŠ et al., Sveta Marija na Dolcu: mala monografija župe, redaktor Juraj LONČAREVIĆ, Župni ured sv. Marije - Kršćanska sadašnjost, Zagreb, 1985., 40.

4 Gradski muzej Varaždin (dalje GMV). GMV KPO 7984. „Moja posljednja volja“, oporuka Ferde Pažura, 1897., str. 8.

5 Bosiljka PASKA, „Pažur, Ferdo“, Gimnazija - SC „Gabrijel Santo“ 1636. - 1986., glavni i odgovorni urednik Josip RUNJAK, Savjet SC „Gabrijel Santo“, Varaždin, 1986., 328.

6 HR-DAVŽ 249. Gimnazija Varaždin. Glavni imenik za školsku godinu 1861./1862.

7 HR-DAVŽ 249. Gimnazija Varaždin. Glavni imenik za školsku godinu 1854./1855.

8 Antun CUVAJ, Građa za povijest školstva kraljevina Hrvatske i Slavonije od najstarijih vremena do danas, svezak IV.: Od 31. prosinca 1851. do 20. listopada 1860., drugo ispravljeno i popunjeno izdanje, Trošak i naklada Kr. hrv. slav. dalm. zem. vlade, Odjela za bogoštovlje i nastavu, Zagreb, 1910., 229.

9 Školske svjedodžbe Ferde Pažura čuvaju se u Gradskom muzeju Varaždin. (Spomenka TEŽAK, kataloške jedinice u: Gimnazijskih 380 godina, katalog izložbe, Prva gimnazija Varaždin, Varaždin, 2016., 41.).

10 GMV 88100. Gimnazijalna svedočba Ferde Pažura za prvo polugodište školske godine 1861./1862.; 
školovanja živio je u Vidovskoj ulici u Varaždinu, danas Ulici Tome Blažeka. Ispit zrelosti položio je 1862 . godine. ${ }^{11}$

\section{UČITELSKA SLUŽBA U VARAŽDINSKOJ GIMNAZIJI}

Netom nakon završetka školovanja u dobi od 17 godina Ferdo Pažur zaposlen je u varaždinskoj gimnaziji kao namjesni učitelj, odnosno suplent, pripravnik. ${ }^{12}$ Bio je nastavnik latinskog, hrvatskog i njemačkog jezika te zemljopisa. Ujedno je bio razrednik prvoga razreda u koji su bila upisana 82 učenika. Godine 1862. dobio je potporu Visoke kraljevske dvorske kancelarije za nastavak školovanja na bečkome sveučilištu u svrhu priprave za gimnazijsko učiteljstvo. ${ }^{13}$ Krajem školske godine 1862./1863. odlazi na školovanje u Beč, a na njegovo radno mjesto dolazi Mirko Divković. U Beču Pažur studira klasičnu filologiju i slavistiku. ${ }^{14}$ Bio je među najboljim klasičnim filolozima, ali nije položio stručni ispit za nastavnika te po povratku u Hrvatsku i dalje radi kao suplent. ${ }^{15}$ Prvotno je zaposlen u osječkoj i požeškoj gimnaziji, a potom dobiva radno mjesto suplenta u Kraljevskoj gimnaziji u Varaždinu. U prvome polugodištu školske godine 1869./1870. predavao je latinski, hrvatski i njemački jezik, a u drugome polugodištu latinski i hrvatski jezik. ${ }^{16}$ Također je obnašao dužnost razrednika u prvome razredu. Ferdo Pažur predavao je hrvatski jezik svojem 17-godišnjem bratu Josipu koji je tada polazio osmi razred gimnazije. ${ }^{17}$ Sljedeće školske godine nastavlja predavati latinski i hrvatski jezik te zadržava razredništvo. ${ }^{18}$ Ferdo Pažur bio je izvrstan nastavnik kojeg su

HR-DAVŽ 249. Gimnazija Varaždin. Glavni imenik za školsku godinu 1861./1862.

11 HR-DAVŽ 249. Gimnazija Varaždin, Kr. velika gimnazija u Varaždinu. Zapisnici ispita zrelosti od 1854./1855. do 1865./1866. školske godine, zapis za šk. god. 1861./1862.

12 HR-DAVŽ 249. Gimnazija Varaždin. Glavni imenik za školsku godinu 1862./1863.

13 Prva gimnazija Varaždin, digitalizirana građa (dalje PG VŽ). Program kraljevske gimnazije u Varaždinu koncem školske godine 1864., Brzotiskom narodne tiskarnice Dra. Ljudevita Gaja, Zagreb, 1864., 32.

14 Ivan MILČETIĆ, „Ferdo Pažur (nekrolog)“, Savremenik: mjesečnik Društva hrvatskih književnika, godina VI., urednik dr. Branimir VIZNER-LIVADIĆ, Društvo hrvatskih književnika, Zagreb, 1911., 377.

15 B. PASKA, n. dj., 328; Antun CUVAJ, Građa za povijest školstva kraljevina Hrvatske i Slavonije od najstarijih vremena do danas, svezak V.: Od 20. listopada 1860. do 20. travnja 1868., drugo ispravljeno i popunjeno izdanje, Trošak i naklada Kr. hrv. slav. dalm. zem. vlade, Odjela za bogoštovlje i nastavu, Zagreb, 1910., 294.

16 Gradska knjižnica i čitaonica „Metel Ožegović“ Varaždin (dalje Knjižnica VŽ). Zavičajna zbirka, sign. 371(091) IZVESTJE 1870. Izvestje kraljevske gymnazije varaždinske koncem školske godine 1870., Brzotiskom Platzera i sina, Varaždin, 1870., 27.

17 HR-DAVŽ 249. Gimnazija Varaždin. Glavni imenik za školsku godinu 1869./1870.

18 PG VŽ. Izvestje kraljevske gimnazije varaždinske koncem školske godine 1870./1871., Brzotiskom 
ANA ŠKRILJEVEČKI: Ferdo Pažur (1845. - 1911.). Zaboravljeni varaždinski klasični filolog i prevoditelj

njegovi učenici iznimno cijenili. ${ }^{19}$ Ujedno se istaknuo kao darovatelj gimnazijske knjižnice te zbirke novaca i starina. ${ }^{20}$ Za vrijeme rada u varaždinskoj gimnaziji održavao je javna predavanja u sklopu djelovanja narodne čitaonice koja u to vrijeme nosi naziv „Dvorana“. Uz Pažura varaždinskim su građanima predavali drugi gimnazijski profesori, među kojima su Josip Križan, Stjepan Kučak, Ivan Pavec, Leonardo Jurmić i Adolf Jurinac. Predavanja su organizirana s ciljem otpora germanizaciji te jačanja nacionalne svijesti. ${ }^{21} \mathrm{U}$ ožujku 1870. godine Ferdo Pažur izlagao je na hrvatskom jeziku o kazalištu za krasni varaždinski spol, a u prosincu iste godine ob uzgoju naše mladeži. ${ }^{22} \mathrm{U}$ listopadu 1871. godine ponovno dobiva potporu za nastavak školovanja na bečkome sveučilištu te prestaje raditi u varaždinskoj gimnaziji. ${ }^{23}$ Nakon kratkog školovanja u Beču vraća se u Hrvatsku te predaje u Kraljevskoj velikoj gimnaziji u Osijeku. U svojoj oporuci Ferdo Pažur navodi da je još 1876 . godine službovao kao gimnazijski učitelj. ${ }^{24} \mathrm{U}$ varaždinskoj gimnaziji više nije predavao.

Platzera i sina u Varaždinu, Varaždin, 1871., 39.

19 „Iz života Ferdinanda Pažura“, Hrvatske pravice, 29. travnja 1911., br. 17, str. 1.

20 PG VŽ. Program kraljevske gimnazije u Varaždinu koncem školske godine 1864., Berzotiskom Narodne tiskarnice Dra. Ljudevita Gaja, Zagreb, 1864., 26; Izvestje kraljevske gimnazije varaždinske koncem školske godine 1870./1871., Brzotiskom Platzera i sina u Varaždinu, Varaždin, 1871., 42; Izvješće kralj. velike gimnazije u Varaždinu koncem školske godine 1884./1885., Tiskarski zavod Platzera sina, Varaždin, 1885., 57; Izvješće kralj. velike gimnazije u Varaždinu koncem školske godine 1886./1887., Tiskarski zavod Platzera sina, Varaždin, 1887., 52; Knjižnica VŽ, Zavičajna zbirka, sign. 371(091) IZVJG 1932. Krešimir FILIĆ, „,Knjižnica varaždinske gimnazije“, Godišnji izvještaj državne realne gimnazije u Varaždinu 1932 - 33, Tisak Stiflerove tiskare, Varaždin, 1933., 10.

21 „Jedna stranica iz povjesti grada Varaždina“, Hrvatske pravice, 21. prosinca 1907., br. 30, str. 10; Rudolf HORVAT, Povijest grada Varaždina, Hrvatska akademija znanosti i umjetnosti, Zavod za znanstveni rad u Varaždinu, Grad Varaždin, Varaždin, 1993., 364-365; Siniša HORVAT, „Krešimir Filić - djelatnik u Varaždinskoj Gimnazijskoj ekstenzi“, Radovi Zavoda za znanstveni rad Varaždin, br. 23, Hrvatska akademija znanosti i umjetnosti, Zavod za znanstveni rad Varaždin, Zagreb - Varaždin, 2012., 129130.

22 „'Prijateljeva' torba“, Pučki prijatelj, 31. ožujka 1870., br. 10, str. 45; „'Prijateljeva’ torba“, Pučki prijatelj, 10. studenoga 1870., br. 42, str. 200.

23 PG VŽ. Izvjestje kraljevskoga gimnazija varaždinskoga koncem školske godine 1871./1872., Berzotiskom Platzera i sina u Varaždinu, Varaždin, 1872., 35.

24 GMV KPO 7984. „Moja posljednja volja“, oporuka Ferde Pažura, 1897., str. 1. 
Radovi Zavoda za znanstveni rad HAZU Varaždin; br. 31, 2020, str. 159-188

\section{OVISNOST O ALKOHOLU, DUŠEVNE BOLESTI I SMRT}

Posljednje razdoblje života Ferdo Pažur proveo je u Varaždinu. Nikad se nije ženio i nije imao djece. Postao je ovisan o alkoholu, duševno je obolio te se u nekoliko navrata pokušao izliječiti. U Javnoj općoj bolnici milosrdne braće u Zagrebu liječen je od 2. kolovoza 1877 . do 7. svibnja 1878. godine. U liječničkoj svjedodžbi Ferde Pažura koju potpisuje liječnik Ladislav Rakovac navodi se da bolesnik pati od fixnih ideah o progonstvu uz halucinacije sluha i vida. ${ }^{25} \mathrm{Iz}$ te bolnice otpušten je poboljšanog stanja. Po povratku u Varaždin stavljen je pod petomjesečni zdravstveni nadzor gradskog fizika Kamile Beila koji ga je naposljetku proglasio duševno podpuno zdravim. ${ }^{26} \mathrm{U}$ to vrijeme Ferdo Pažur nije imao stalno zaposlenje i obavljao je razne poslove. Kako sam navodi, radio je kao dnevničar, odnosno uredski službenik u gradskoj upravi. ${ }^{27}$ Također je davao instrukcije gimnazijalcima. Učenike je podučavao u svim predmetima, osobito u klasičnim jezicima te hrvatskom i njemačkom. ${ }^{28}$ Stanovao je na Sajmištu br. 1 u Varaždinu. Bolovao je od hernije i teško je živio. Po nalogu nakladnika J. B. Stiflera prevodio je grčke i rimske klasike za što je dobivao minimalnu naknadu. ${ }^{29}$ Zahvaljujući navedenim prijevodima postao je omiljen među učenicima varaždinske gimnazije kojima je znatno olakšao učenje i prevođenje. ${ }^{30}$ Pažur se uzdržavao i zaradom za izvorno djelo koje je u to vrijeme napisao. ${ }^{31}$ Međutim, njegove psihičke smetnje

25 GMV KPO 7985. Liječnička svjedodžba Ferde Pažura, Javna obća bolnica braće milosrdne, Zagreb, 7. svibnja 1878. godine.

26 GMV KPO 7986. Liječnička svjedodžba Ferde Pažura, Varaždin, 4. listopada 1878. godine.

27 Na liječničku svjedodžbu (GMV KPO 7986) Ferdo Pažur zapisao je 27. kolovoza 1898. godine dodatak u kojem moli varaždinskoga gradskog načelnika za zaostalu plaću. U molbi spominje da je neko vrijeme bio "dnevničarom kod grada“.

28 „Domaće viesti“, Hrvatska pošta, 6. srpnja 1898., br. 14, str. 3; „Domaće viesti“, Hrvatska pošta, 16. studenoga 1898., br. 34, str. 2.

29 „Iz života Ferdinanda Pažura“, Hrvatske pravice, 29. travnja 1911., br. 17, str. 1; Luka GOLUB, „Iz mojih uspomena (Doba od 1894-1902)“, Spomenica Varaždinske gimnazije: 1636-1936, uredio Krešimir FILIĆ, Tiskara Slobodine „Narodne tiskare“, Varaždin, 1937., 136-137; I. MILČETIĆ, n. dj., 377.

30 Književnik Stjepan Parmačević prisjeća se Ferde Pažura u Spomenici Varaždinske gimnazije: 1636. 1936 ovim riječima: „Među svojim zidinama krio je taj grad, pored pomenutih, još i mnogo drugih ljudi koji su rasvjetljavali, bilo čim, naše mlade duhove. Starog penzionisanog profesora Pažura, sa herniom do koljena, svi smo smatrali svojim dobročincem. $U$ dokonim časovima svoga penzionerskog života, uvijek u starom crnom salonroku, on je štampao prijevode grčkih klasika koje smo čitali u školi.“ (Stjepan PARMAČEVIĆ, „Uz tristagodišnjicu varažd. gimnazije“, Spomenica Varaždinske gimnazije: 1636 - 1936, uredio Krešimir FILIĆ, Tiskara Slobodine „Narodne tiskare“, Varaždin, 1937., 41-42.). Ivo Frangeš također navodi da je Ferdo Pažur bio dobro poznati đacima te da je imao legendarni status. (Ivo FRANGEŠ, Nove stilističke studije, Globus, Zagreb, 1986., 111.).

31 „Književnost i umjetnost“, Hrvatska straža, 14. kolovoza 1886., br. 33, str. 4. 
ANA ŠKRILJEVEČKI: Ferdo Pažur (1845. - 1911.). Zaboravljeni varaždinski klasični filolog i prevoditelj

nisu potpuno nestale. Profesor Luka Golub je kao gimnazijalac posjetio Ferdu Pažura kada je on živio na Ledinama u jednoj sobici niske, vlažne seljačke kuće. ${ }^{32}$ Na temelju njegovih zapisa vidljivo je da su Pažura i dalje mučile halucinacije i manije proganjanja. Pažurovo duševno stanje može se također iščitati iz njegove oporuke koju je započeo pisati 28. lipnja 1897. godine. ${ }^{33} \mathrm{U}$ oporuci su zapisane Pažurove muke u obliku dnevnika. U tekstu prevladava snažan strah od tragičnog svršetka života. Naime, Pažur navodi da je od 1876. godine njekim tvarima injiciran te uslijed toga elektromagnetičan, zatim razlaže načine borbe za svoju baštinu, koja dolazi od carice Euženije i princeva Napoleona, i neprestano spominje svoje neprijatelje, među njima i vlastitoga brata (nebrata) Josipa Pažura, koji ga progone i muče te ga nastoje ubiti zbog njegova naslijeđa. ${ }^{34}$ Pažurova oporuka jasno pokazuje koliko je trpio zbog duševnih bolesti i da nije primao odgovarajuću liječničku skrb. Ferdo Pažur skončao je život u varaždinskoj gradskoj ubožnici. ${ }^{35}$ Riječ je o hospitalu, zdravstveno-socijalnoj ustanovi, smještenom u današnjoj Prešernovoj ulici (stari kućni broj 10) gdje su u Pažurovo vrijeme (od 1905. godine) sestre milosrdnice njegovale štićenike. ${ }^{36}$ Premda se nije radilo o bolnici, zbog te ustanove, Prešernova ulica prozvana je Bolničkom. ${ }^{37}$ Vijest o njegovoj smrti objavilo je nekoliko novina. Hrvatske pravice izvijestile su da je 21. travnja 1911. godine nakon kratke bolesti u 66. godini umro Ferdo Pažur, bivši gimnazijalni učitelj i književnik, koji je primivši posljednje sakramente izjavio: „O kako sam lijepo obavio svoju kršćansku dužnost!". ${ }^{8}$ U sljedećem broju Hrvatske pravice objavile su nekrolog posvećen Pažuru. ${ }^{39} U$ tekstu je iznesen kratki pregled Pažurova života i djela. Istaknuto je Pažurovo odlično poznavanje klasičnih i modernih jezika te njegovo literarno stvaralaštvo. Navodi se da je Pažur spjevao nekoliko hrvatskih pjesama ljubavne tematike i jednu pjesmu na latinskom jeziku u elegijskom distihu, koje nisu objavljene te su sačuvane u njegovom dnevniku. Prema

32 L. GOLUB, n. dj., 136-137.

33 GMV KPO 7984. „Moja posljednja volja“, oporuka Ferde Pažura, 1897., str. 1-26.

34 Isto, 1, 6-9, 15-19, 22, 26.

35 R. HORVAT, n. dj., 497; Ivan Milčetić u nekrologu (I. MILČETIĆ, n. dj., 377.) navodi da je Pažur u ubožnici proživio posljednjih 20 godina života, ali taj podatak nije točan jer je Pažur još 1898. godine davao instrukcije iz svojeg stana na Sajmištu u Varaždinu. („Domaće viesti“, Hrvatska pošta, 16. studenoga 1898., br. 34, str. 2.).

36 Gustav PIASEK i Martina PIASEK, „Tradicija hospitala (ksenodohija) u Varaždinu“, Arhiv za higijenu rada i toksikologiju 57, br. 4, Institut za medicinska istraživanja i medicinu rada, Zagreb, 2006., 459, 464.

37 Isto, 464.

38 „Ferdo Pažur", Hrvatske pravice, 22. travnja 1911., br. 16, str. 5.

39 „Iz života Ferdinanda Pažura“, Hrvatske pravice, 29. travnja 1911., br. 17, str. 1-2. 
Hrvatskim pravicama zbog prijevoda grčkih i rimskih klasika Ferde Pažura ne će biti gimnazijalca u cijeloj Hrvatskoj, koji to ime ne bi poznavao a ujedno mu i ne bi bio zahvalan. ${ }^{40}$ Za razliku od opširne posvete u Hrvatskim pravicama, novine Naše pravice ukratko su izvijestile da je umro gimnazijski učitelj i književnik Ferdo Pažur koji se odlikovao svojom klasičnom naobrazbom, te je vječna šteta, da ga bolest već u ranijim godinama odkinula od njegova zvanja. ${ }^{41}$ Sahranjen je na varaždinskom gradskom groblju. ${ }^{42} \mathrm{U}$ nekrologu Ivan Milčetić navodi da su Pažura na posljednji počinak ispratili gimnazijalci sa svojim učiteljima, a varaždinski profesori tom su prigodom prikupili mali iznos za dobrotvorne svrhe. ${ }^{43}$ Antun Cuvaj svrstao je Ferdu Pažura među zaslužne pokojnike Kraljevske velike gimnazije u Varaždinu. ${ }^{44}$ Nakon smrti Pažura njegovim su se prijevodima nastavile koristiti mnogobrojne generacije gimnazijalaca. ${ }^{45}$

\section{PAŽUROVI PRIJEVODI}

Opus Ferde Pažura možemo podijeliti u prijevode i izvorna djela. Prvoj skupini pripadaju prijevodi grčkih i rimskih klasika te priručnici. Prijevodi Ferde Pažura izašli su u Stiflerovoj nakladi te zauzimaju značajno mjesto među tiskovinama ove varaždinske tiskare. ${ }^{46}$ Klasifikaciju Pažurovih prijevoda grčkih i rimskih književnih djela izradio je hrvatski klasični filolog i prevoditelj Zlatko Šešelj u svojem radu „Bibliografija prijevoda klasične grčke i rimske književnosti“. ${ }^{47}$ Prema Šešelju Pažurovi prijevodi objavljivani su od 1896. do 1911. godine. Knjige nisu datirane, pa Šešelj radi približnu dataciju i smješta djela u tri razdoblja. U prvome razdoblju (1896.-1902.) grafička forma objavljenih djela nije standardizirana. U

40 Isto, 1.

41 „Ferdo Pažur“, Naše pravice, 27. travnja 1911., br. 17, str. 4.

42 „Ferdo Pažur", Hrvatske pravice, 22. travnja 1911., br. 16, str. 5.

43 I. MILČETIĆ, n. dj., 377.

44 Antun CUVAJ, Građa za povijest školstva kraljevina Hrvatske i Slavonije od najstarijih vremena do danas, svezak X.: Od 31. listopada 1888. do danas, Drugo ispravljeno i popunjeno izdanje, Trošak i naklada Kr. hrv. slav. dalm. zem. vlade, Odjela za bogoštovlje i nastavu, Zagreb, 1913., 327.

45 Dr. Gustav PIASEK, „Poznati Varaždinci. Ferdo Pažur“, Varaždinske vijesti, 8. svibnja 1996., br. 19, str. 9.

46 Magdalena LONČARIĆ, Tiskarstvo u Varaždinu 1586. - 1946., katalog izložbe, TIVA Tiskara Varaždin Gradski muzej Varaždin, Varaždin, 2007., 31.

47 Zlatko ŠEŠELJ, „Bibliografija prijevoda klasične grčke i rimske književnosti u knjigama i zbirnim izdanjima 1900-1918.", Latina et Graeca, vol. 1, br. 15, Latina et Graeca, Institut za klasične jezike i antičku civilizaciju, Zagreb, 1980., 69-97. URL: https://hrcak.srce.hr/223472 (Datum pristupa: 28. srpnja 2020.). 
ANA ŠKRILJEVEČKI: Ferdo Pažur (1845. - 1911.). Zaboravljeni varaždinski klasični filolog i prevoditelj

drugome razdoblju (1903.) knjige su tiskane unutar Zbirke prijevoda rimskih $i$ grčkih klasika u prozi. U trećem razdoblju (1904.-1911.) knjige i dalje pripadaju Zbirci prijevoda rimskih i grčkih klasika u prozi, imaju standardiziranu naslovnicu, ali nedostaje numeracija. ${ }^{48} \mathrm{U}$ prvo razdoblje Šešelj smješta ukupno 13 naslova. Riječ je o prijevodima djela Tita Livija, Cezara, Ovidija Nazona, Vergilija, Ksenofonta i Platona. U drugo razdoblje spada 10 naslova; prijevodi Cicerona, Homera, Tita Livija, Ovidija Nazona, Platona i Tacita. Posljednje razdoblje obuhvaća 9 prijevoda djela Horacija, Cicerona, Tita Livija, Ovidija Nazona i Salustija Krispa. Među navedene naslove Šešelj ne svrstava Devet govora Demosthenovih nego tvrdi da je knjiga izdana poslije smrti Ferde Pažura. ${ }^{49}$ Kao prevoditelj navedenog djela na prednjoj korici i naslovnici zapisan je V. R. (Vatroslav Rožić?) ${ }^{50}$ iako se na zadnjoj korici knjige među popisanim prijevodima Ferde Pažura navode i Demosthenovi govori. ${ }^{51}$ Moguće da se radi o pogrešnoj atribuciji Rožiću jer se ne spominje drugi prijevod Demostena koji bi priredio Ferdo Pažur. U prilog tome ide činjenica da rad Vatroslava Rožića nije vezan za klasičnu filologiju. ${ }^{52}$ Također, po jezičnim karakteristikama djelo ne odudara od ostalih Pažurovih prijevoda. Precizni, ali stilski nedorađeni, Pažurovi prijevodi praktične su naravi i ponajprije su namijenjeni školskoj upotrebi. ${ }^{53} \mathrm{Njima}$ su se koristili učenici klasičnih gimnazija u Austro-Ugarskoj Monarhiji i Kraljevini Srbiji, a bili su iznimno traženi čak u Bugarskoj. ${ }^{54}$ Golub navodi da su pisani čudnim jezikom i strašnim stilom, ali su dobro došli učenicima koji su se rado njima služili, jer je prijevod bio doslovan. ${ }^{55}$ Prilikom korištenja Pažurovih prijevoda dodatne poteškoće predstavljaju vrlo rijetke

48 Isto, 70.

49 Isto, 88.

50 U katalogu Zavičajne zbirke Gradske knjižnice i čitaonice „Metel Ožegović“ Varaždin inicijali su razriješeni u Vatroslav Rožić. Warasdiniensia - Digitalizirana zavičajna zbirka Gradske knjižnice i čitaonice „Metel Ožegović“ Varaždin (dalje Warasdiniensia), Naslov: Devet govora Demosthenovih. URL: https://library.foi.hr/zbirke/varazdin/ (Datum pristupa: 4. kolovoza 2020.).

51 Knjižnica VŽ, Zavičajna zbirka, sign. 938 DEMOS dev. Devet govora Demosthenovih, po A. Musiću, preveo V. R., Zbirka prijevoda rimskih i grčkih klasika u prozi, Tisak i naklada J. B. Stiflera, Varaždin, s. a., zadnja korica.

52 Marko SAMARDŽIJA, „Vatroslav Rožić. Predgovor“, Jezikoslovne rasprave i članci, Franjo IVEKOVIĆ et al.; priredio Marko SAMARDŽIJA, Matica hrvatska, Zagreb, 2001., 227-236.

53 Antun GOLOB, „Teški radni uvjeti varaždinskih grafičara“, Varaždinske vijesti, 28. veljače 1985., br. 8, str. 2; S. PARMAČEVIĆ, n. dj., 42.

54 I. MILČETIĆ, n. dj., 377; Krešimir FILIĆ, „O radu starih varaždinskih tiskara: Štrajk grafičara 1890. godine“, Varaždinske vijesti, 28. rujna 1961., br. 814, str. 4; Marijan KRAŠ, „'Varasdiniensia' - zavičajna zbirka Gradske knjižnice i čitaonice 'Sloboda', Varaždin“, Vjesnik bibliotekara Hrvatske, 17/1971., glavni i odgovorni urednik Branko HANŽ, Hrvatsko bibliotekarsko društvo, Zagreb, 1971., 102.

55 L. GOLUB, n. dj., 136. 
bilješke, a uvodni i popratni tekstovi nedostaju u većini djela. Varijante prijevoda odnosno vokabulara donijete su u dopunskim zagradama u tekstu. ${ }^{56}$ Stoga, prednosti Pažurovih prijevoda su vjernost izvorniku i gramatička točnost, a nedostaci otežano čitanje i razumijevanje zbog umetnutih varijanti i pojašnjenja u tekst, nepostojanje filologijskih objašnjenja, komentara te dubljeg logičkog i kritičkog čitanja, te najvažnije, što se ne navodi izdanje izvornika. ${ }^{57}$ Marijan Kraš zaključuje da izdanja grčkih i rimskih klasika u prijevodu Ferde Pažura izvanredno ilustriraju kulturni život Varaždina u prošlosti i njegovo duhovno bïlo. ${ }^{58}$

U popisu Pažurovih prijevoda na stražnjim koricama Demostena ${ }^{59}$ spominju se dva djela koja nisu prijevodi grčkih i rimskih klasika nego priručnici za učenje latinskog jezika. Prvi naslov glasi: Lhomond, o slavnijem muževima grada Rima od Romula do Augusta. Riječ je o priručniku Urbis Romae Viri Illustres: A Romulo Ad Augustum francuskoga latinista Charlesa Françoisa L'Homonda (Lhomonda) u Holzerovoj redakciji na njemačkom jeziku iz 19. stoljeća, koji se koristio kao obavezna literatura za latinski jezik u trećem razredu gimnazije, ali u prijevodu Franje Marna, a ne Ferde Pažura. ${ }^{60}$ Prilikom uvida u katalog Nacionalne i sveučilišne knjižnice u Zagrebu, Hrvatski nacionalni skupni katalog i katalog Zavičajne zbirke Gradske knjižnice i čitaonice „Metel Ožegović“ Varaždin nije pronađen primjerak koji je priredio Pažur. ${ }^{61}$ Drugi je naslov Mali Latinac: vademecum svih pravila latinske slovnice sa svim nepravilnim glagolima. Primjerak priručnika Mali Latinac čuva se u Gradskoj knjižnici i čitaonici „Metel Ožegović“ Varaždin, ali autor djela nije naznačen. ${ }^{62}$ Ne postoji uvod u knjigu tako da nije jasno na temelju kojeg izvornika je priređen navedeni priručnik. ${ }^{63} \mathrm{U}$ prvome su dijelu iznesena kratka

56 I. FRANGEŠ, n. dj., 111; Z. ŠEŠELJ, n. dj., 73.

57 Petar ŠEGEDIN, „Prijevodi Platonovih djela na hrvatski jezik“, Prilozi za istraživanje hrvatske filozofske baštine 29., br. 1-2 (57-58), Institut za filozofiju, Zagreb, 2003., 391-392. URL: https://hrcak.srce. hr/68585 (Datum pristupa: 29. srpnja 2020.).

58 M. KRAŠ, n. dj., 102.

59 Knjižnica VŽ, Zavičajna zbirka, sign. 938 DEMOS dev. Devet govora Demosthenovih, zadnja korica.

60 PG VŽ. Izvještaj kr. velike gimnazije u Varaždinu za školsku godinu 1905. - 6., Knjigotiskara J. B. Stiflera, Varaždin, 1906., 7, 25, 26; Izvještaj kralj. velike gimnazije u Varaždinu za školsku godinu 1907. - 1908., Tiskara Stjepana pl. Platzera, Varaždin, 1908., 6, 23, 24.

61 Nacionalna i sveučilišna knjižnica u Zagrebu, 2020., Katalog (dalje NSK katalog), Odrednica: Lhomond, Charles François, Autor: Pažur, Ferdo. URL: http://katalog.nsk.hr/ (Datum pristupa: 4. kolovoza 2020.); Hrvatski nacionalni skupni katalog (dalje Skupni katalog), Autor: Pažur, Ferdo. URL: http:// skupnikatalog.nsk.hr/ (Datum pristupa: 4. kolovoza 2020.); Warasdiniensia. Autor: Pažur, Ferdo. URL: https://library.foi.hr/zbirke/varazdin/ (Datum pristupa: 4. kolovoza 2020.).

62 Knjižnica VŽ, Zavičajna zbirka, sign. 811.124 MALI. Mali Latinac: vademecum svih pravila latinske slovnice sa svim nepravilnim glagolima, Tisak i naklada J. B. Stiflera, Varaždin, s. a.

63 U bilješci u djelu usputno se spominje da je riječ o njemačkom izvorniku. Mali Latinac, str. 115, bilješka. 
ANA ŠKRILJEVEČKI: Ferdo Pažur (1845. - 1911.). Zaboravljeni varaždinski klasični filolog i prevoditelj

pravila gramatike latinskog jezika uz prozodiju kao dodatak, a drugi dio čini pregled nepravilnih glagola. Djelo je napisano jasno i pregledno uz mnoštvo primjera na latinskom jeziku.

\section{IZVORNA DJELA}

Uvidom u Hrvatski nacionalni skupni katalog, knjižnicu Gradskog muzeja Varaždin te kataloge Nacionalne i sveučilišne knjižnice u Zagrebu, Knjižnice Uršulinskog samostana Varaždin i Zavičajne zbirke Gradske knjižnice i čitaonice „Metel Ožegović “ Varaždin ${ }^{64}$ ustanovljeno je da su objavljena ukupno četiri izvorna djela Ferde Pažura. Kada gledamo kronološki, najstarije je djelo studija „O desetercu junačkih naših pjesama“ koju je Pažur napisao za vrijeme službovanja u osječkoj gimnaziji te je objavljena 1873. godine u Izvještaju osiječke gim. god. $1872-3 .{ }^{65} \mathrm{U}$ njoj se Pažur istaknuo kao vrsni poznavatelj hrvatske narodne poezije. ${ }^{66}$ Pažur u djelu po naglasku analizira različite obrasce deseterca potkrepljujući ih primjerima iz narodnih pjesama, no Luka Zima zaključuje da takav Pažurov pristup ipak ima određene manjkavosti. ${ }^{67}$

Potom slijedi Pažurovo najpoznatije djelo Filozofijsko-filologijske razprave koje je objavljeno 1886. godine. ${ }^{68} \mathrm{Knjiga}$ se sastoji od tri dijela od kojih prvi govori o postanku jezika, drugi o genetičko-sintaktičnim mislima, a treći o čestici (vezniku) „da“ u hrvatskom jeziku. Međutim, tiskan je samo treći svezak jer prva dva Pažur nije dovršio. ${ }^{69}$ Navedeno djelo Pažur nije napisao po nalogu tiskara nego iz vlastitih pobuda. Knjiga je tiskana uz potporu grofa Jakova Eltza. Ujedno je Pažur samostalno promovirao djelo u novinama te primao narudžbe jer knjiga nije bila

64 Skupni katalog. Autor: Pažur, Ferdo. URL: http://skupnikatalog.nsk.hr/ (Datum pristupa: 4. kolovoza 2020.); NSK katalog. Autor: Pažur, Ferdo. URL: http://katalog.nsk.hr/ (Datum pristupa: 4. kolovoza 2020.); Knjižnica Uršulinskog samostana Varaždin. Katalog. Autor: Pažur, Ferdo. URL: https://bit. ly/3h6YSXW (Datum pristupa: 11. kolovoza 2020.); Warasdiniensia. Autor: Pažur, Ferdo. URL: https:// library.foi.hr/zbirke/varazdin/ (Datum pristupa: 4. kolovoza 2020.).

65 NSK katalog. Autor: Pažur, F. URL: http://katalog.nsk.hr/ (Datum pristupa: 4. kolovoza 2020.).

66 „Iz života Ferdinanda Pažura“, Hrvatske pravice, 29. travnja 1911., br. 17, str. 1.

67 Luka ZIMA, „Nacrt naše metrike narodne: obzirom na stihove drugih naroda a osobito Slovenâ", Rad Jugoslavenske akademije znanosti i umjetnosti, knjiga 48, Jugoslavenska akademija znanosti i umjetnosti, Zagreb, 1879., 187.

68 Knjižnica VŽ, Zavičajna zbirka, sign. 808.62 PAŽUR fil. Ferdo PAŽUR, Filozofijsko-filologijske razprave (I. O postanku jezika. II. Genetičko-sintaktične misli. III. Čestica (veznik) "da" u hrvatskom jeziku), treći svezak, Knjigotiskarski zavod Platzerova sina, Varaždin, 1886.

69 Isto, „Priedgovor“. 
dostupna u knjižarama nego se isključivo mogla naručiti od njega. ${ }^{70}$ Pažur javno zahvaljuje u novinama grofu Ladislavu Pejačeviću Virovitičkomu na velikodušnome daru za njegovu knjigu kojim mu je pomogao namiriti velike troškove tiskanja. ${ }^{71} \mathrm{U}$ knjizi je opsežno opisana upotreba čestice (veznika) „da“ potkrijepljena primjerima iz hrvatskog jezika uz detaljne bilješke. Autor također uspoređuje njezino korištenje u klasičnim jezicima. Knjiga je ponajprije namijenjena učenicima kao dodatak obaveznoj školskoj literaturi te učiteljstvu. Iz ovog rada izvire Pažurova ljubav prema hrvatskom jeziku koja je ujedno jedan od razloga pisanja djela. ${ }^{72}$ Osim na hrvatskom jeziku Pažur je napisao djelo na njemačkom. Riječ je o sažetoj, praktičnoj gramatici hrvatskog jezika za Nijemce. ${ }^{73}$ Pažur ju je napisao po nalogu nakladnika Stiflera. Posebnost je knjige njezina namjena za samostalno učenje odraslih, prije svega poslovnih ljudi. Knjiga je prilično iscrpna te ima gotovo tristo stranica. Autor ne ulazi u dublje sintaktičke analize već nastoji pojednostavniti tekst radi što bržeg učenja. ${ }^{74} \mathrm{Uz}$ teorijski dio postoje i korisni zadaci za vježbu s pripadajućim rječnikom koji olakšava prevođenje. Dodatak je knjizi ćirilična abeceda. Udžbenik je praktičan, vrlo pregledan, originalan te metodološki gotovo suvremen, zaključuje Bosiljka Paska. ${ }^{75}$

Posljednje izvorno Pažurovo djelo neobične je tematike u odnosu na preostale autorove radove. Zbirka Novi čestitar za djecu i školsku mladež sastoji se od čestitaka u stihu i prozi povodom nove godine, imendana i rođendana. ${ }^{76}$ Antun Cuvaj

70 „Književnost“, Sriemski Hrvat, 14. srpnja 1886., br. 56, str. 2-3; „Književnost i umjetnost“, Hrvatska straža, 14. kolovoza 1886., br. 33, str. 4.

71 „Javna zahvala“, Narodne novine, 27. veljače 1888., br. 47, str. 3.

72 Pažur u predgovoru navodi: „, (...) htjedoh ovom knjigom, pa još kojom, bude li, kako gore rekoh, života i zgode, da ponovim duševnu svezu, zabavljajući njih i sebe u ovo težko vrieme mirnim, utješljivim poslom, naime predočivanjem i izlaganjem najdivnijega proizvoda srca i uma ljudskoga, izraza našega materijalno idealnoga bića, jezika, te nadalje malenog jednog diela, jedne mrvice neizmjernog tog našega blaga, skladajuće u toli krasan i raznobojan mozaik biser, što je sačuvan u bogatoj riznici milog nam hrvatskoga jezika, blago, koje vazda mora da nam bude amanetom, koje da branimo, za koje valja da svi, ako uztreba, položimo i život svoj!“ (F. PAŽUR, Filozofijsko-filologijske razprave, "Priedgovor").

73 Knjižnica VŽ, Zavičajna zbirka, sign. 811.163.42 PAŽ K. Ferdinand PAŽUR, Kurzgefasste praktische Grammatik der kroatischen Sprache für Deutsche: vorzüglich zum Selbstunterrichte für Erwachsene aller Stände, besonders für Kaufleute, Reisende und Gewerbsleute aller Art bestimmt, J. B. Stifler, Varaždin, [oko 1890.].

74 Isto, predgovor.

75 B. PASKA, n. dj., 329.

76 Knjižnica Uršulinskog samostana Varaždin, sign. Cd-V-251. Ferdo PAŽUR, Novi čestitar za djecu $i$ školsku mladež: zbirka veoma zgodnih čestitaka svim rodjacima i inim o novoj godini, rodjen- $i$ imendanu u pjesmicama i prozi, Tisak i naklada knjižare J. B. Stiflera, Varaždin, s. a. 
ANA ŠKRILJEVEČKI: Ferdo Pažur (1845. - 1911.). Zaboravljeni varaždinski klasični filolog i prevoditelj

datira djelo u 1893. godinu. ${ }^{77}$ Te je godine Ferdo Pažur napisao predgovor u kojem navodi da je djelo sastavio po nalogu knjižare J. B. Stiflera te da je namijenjeno školskoj mladeži. ${ }^{78}$ Prilikom sastavljanja držao se najviše misli, mjerila i dikcije narodne pjesme te će zbog toga učenici imati višestruke koristi, posebice će se lako priviknuti stihu i jeziku narodnog pjesničtva. ${ }^{79}$ Ovom knjigom ponovno dolazi do izražaja ljubav Ferde Pažura prema hrvatskom jeziku. Njegova su djela imala odjeka. Ernest Fišer smješta Ferdu Pažura među hrvatske književne povjesničare čiji doprinos u cjelokupnoj hrvatskoj književnoj historiografiji nije zanemariv. ${ }^{80}$

U katalogu Gradske knjižnice i čitaonice „Metel Ožegović“ Varaždin Ferdo Pažur navodi se kao autor knjige Pučki listar. ${ }^{81}$ Naime, na prednjoj korici Pučkog listara zapisan je Ferdo Pažur kao sastavljač. Međutim, na naslovnoj stranici piše da je djelo sastavio Zvonimir Pužar. Mira Kolar-Dimitrijević pripisuje to djelo Zvonimiru Pužaru (1875.-1926.), hrvatskom pučkom piscu, tipografu i socijalnom radniku, ${ }^{82}$ stoga smatramo da se radi o pogrešnoj atribuciji na korici knjige do koje je najvjerojatnije došlo zbog slične tematike spomenutog djela i Pažurove zbirke Novi čestitar za djecu i školsku mladež.

\section{ZAKLJUČAK}

Životni put Ferde Pažura prikazan u radu ponajprije je vezan za njegov rodni grad Varaždin gdje se školuje, drži nastavu, prevodi i piše knjige. Zahvaljujući školskom uspjehu i velikoj darovitosti za jezike zaposlen je u varaždinskoj gimnaziji. lako je u toj ustanovi predavao samo tri školske godine, zauvijek se utisnuo u sjećanje svojih učenika koji su cijenili njegov trud uložen u obrazovanje novih naraštaja.

77 A. CUVAJ, Građa za povijest školstva kraljevina Hrvatske i Slavonije od najstarijih vremena do danas, svezak X., 616.

78 Knjižnica Uršulinskog samostana Varaždin, sign. Cd-V-251. F. PAŽUR, Novi čestitar za djecu i školsku mladež, „Prijedgovor".

79 Isto, „Prijedgovor".

80 Ernest FIŠER, „Varaždin kao rasadište hrvatskih književnih povjesničara“, Zbornik o Branku Vodniku: književnom povjesničaru, Zbornik radova sa znanstvenog skupa Zagreb - Varaždin, 13. - 15. travnja 2000., glavni urednik Tihomil MAŠTROVIĆ, Hrvatski studiji Sveučilišta u Zagrebu, Zagreb, 2001., 418.

81 Knjižnica VŽ, Zavičajna zbirka, sign. 82.0 PAŽUR PUČ. Zvonimir PUŽAR [i. e.] Ferdo PAŽUR, Pučki listar: sbirka svakovrstnih pismenih sastavaka za sve prigode u domaćem, družtvenom i poslovnom životu, Tisak i naklada J. B. Stiflera, Varaždin, s. a.

82 Mira KOLAR-DIMITRIJEVIĆ, „Pučki pisac Zvonimir Pužar i Križevci 1910. - 1923.“, Cris: časopis Povijesnog društva Križevci V/1, Povijesno društvo Križevci, Križevci, 2003., 16-17. URL: https://hrcak. srce.hr/93702 (Datum pristupa: 1. kolovoza 2020.). 
Ipak, Ferdo Pažur postao je omiljen daleko izvan Varaždina zbog svojih prijevoda grčkih i rimskih klasika koji su objavljeni u Stiflerovoj nakladi. Zahvaljujući Pažurovim prijevodima glas o Varaždinu i varaždinskoj tiskari pronio se izvan zemlje. Poznato je više od trideset naslova Pažurovih prijevoda autora klasične grčke i rimske književnosti, redom u prozi, koji su prije svega bili namijenjeni školskoj upotrebi i lakšem učenju grčkog i latinskog jezika. Iz popisa prevođenih djela vidljivo je da se radi o nezaobilaznim piscima u učenju klasičnih jezika i književnosti. Time Pažur nastavlja educirati učenike iako više nije zaposlen kao nastavnik. Sva izvorna djela Ferde Pažura tematski povezuje hrvatski jezik, odnosno autorova duboka odanost hrvatskoj pisanoj riječi. Najviše inovativnosti dolazi do izražaja u Pažurovoj gramatici hrvatskog jezika za poslovne ljude koji govore njemački. Time Pažur radi iskorak te sastavlja djelo, koje je za razliku od preostalih njegovih radova napisanih za učenike, namijenjeno obrazovanju odraslih. Pažurova sveobuhvatna gramatika vrijedan je doprinos razumijevanju hrvatskog jezika i širenju njegove upotrebe. Uspoređujući Pažurova izvorna djela s njegovim prijevodima, uočljivo je da originalne knjige ne piše nužno po nalogu nakladnika nego iz vlastitih motiva. Dapače, Filozofijsko-filologijske razprave sam predstavlja te promovira u novinama. Zapanjuje činjenica da je pokazao toliku lucidnost u stvaranju te neumoran rad na novim naslovima unatoč teško narušenom duševnom zdravlju.

Oskudna literatura o Pažuru jedan je od razloga što on pripada zaboravljenim varaždinskim stvarateljima. Stoga smo u ovom radu predstavili život i djelovanje Ferde Pažura koji zbog svojeg književnog nasljeđa zaslužuje spas iz zaborava. Pažurova djela plod su briljantnosti i požrtvovnosti autora koji je čitav život posvetio obrazovanju učenika i njegovanju hrvatskoga jezika.

\section{BIBLIOGRAFIJA FERDE PAŽURA}

\section{a) Prijevodi ${ }^{83}$}

1/ Povijesti rimske Tita Livija od sazdanja grada Rima, knjiga I., preveo Ferdo PAŽUR, Nakladom i tiskom J. B. Stiflera, Varaždin, s. a., [1896.?].

2) Povijesti rimske Tita Livija od sazdanja grada Rima, knjiga II., preveo Ferdo PAŽUR, Nakladom i tiskom J. B. Stiflera, Varaždin, s. a., [1896.].

83 Popis prijevoda temelji se na bibliografiji Z. Šešelja (Z. ŠEŠEL,, n. dj., 69-97.) uz dodatak Devet govora Demosthenovih, koje Šešelj ne pripisuje Pažuru, te dva priručnika: Lhomond i Mali Latinac. 
ANA ŠKRILJEVEČKI: Ferdo Pažur (1845. - 1911.). Zaboravljeni varaždinski klasični filolog i prevoditelj

3/ Cezar, Galski rat, preveo Ferdo PAŽUR, Nakladom i tiskom J. B. Stiflera, Varaždin, s. a., [1900.?].

4/ Povijesti rimske Tita Livija od sazdanja grada Rima, [knjige III., IV., VI.?], preveo Ferdo PAŽUR, s. a., [oko 1900.?].

5/ Povijesti rimske Tita Livija od sazdanja grada Rima, knjiga XXI., preveo Ferdo PAŽUR, Varaždin, s. a., [oko 1900.?].

6) Povijesti rimske Tita Livija od sazdanja grada Rima, knjiga XXII., preveo Ferdo PAŽUR, s. a., [oko 1900.?].

7/ Izabrane pjesme P. Ovidija Nazona, preveo za porabu školsku (IV. i V. gimn. razr.) po knjizi prof. L. Jurmića Ferdo PAŽUR, Tisak i nakl. J. B. Stiflera, Varaždin, s. a., [1900.?].

8/ Vergilijeve pjesme, preveo Ferdo PAŽUR, Nakladom i tiskom J. B. Stiflera, Varaždin, s. a., [oko 1900.?].

9/ Vergilijeve pjesme (izbor): za školsku porabu, svezak I., preveo Ferdo PAŽUR, Nakladom i tiskom J. B. Stiflera, Varaždin, s. a., [oko 1900.?].

10/ Vergilijeve pjesme (izbor): za školsku porabu, svezak II., preveo Ferdo PAŽUR, Nakladom i tiskom J. B. Stiflera, Varaždin, s. a., [1900.?].

11/ Dr Karla Šenkla Hrestomatija iz Ksenofonta po hrvatskom izdanju prof. Leonh. Jurmića, preveo Ferdo PAŽUR, J. B. Stifler, Varaždin, s. a., [1901.?].

12/ Povijesti rimske Tita Livija od sazdanja grada Rima, knjige XXI., XXII., svezak I. (knjiga XXI.), preveo Ferdo PAŽUR, Tisak i naklada J. B. Stiflera, Varaždin, s. a., [1901.?].

13/ Platonov Protagora: (nadrimudraci): filozofički razgovor o krijeposti, preveo Ferdo PAŽUR, J. B. Stifler, Varaždin, s. a., [1902.].

14/ Ciceronov govor o vrhovnom zapovjedništvu Kn. Pompeja, preveo Ferdo PAŽUR, Zbirka prijevoda rimskih i grčkih klasika u prozi, svezak 9, Tisak i naklada J. B. Stiflera, Varaždin, s. a., [1903.].

15/ Ciceronov govor za Tita Annija Milona, preveo Ferdo PAŽUR, Zbirka prijevoda rimskih i grčkih klasika u prozi, svezak 1, Tisak i naklada J. B. Stiflera, Varaždin, s. a., [1903.].

16/ Ciceronovi govori (I-IV) proti L. Katilini: po tekstu školskoga izdanja, preveo Ferdo PAŽUR, Zbirka prijevoda rimskih i grčkih klasika u prozi, svezak 8, Tisak i naklada J. B. Stiflera, Varaždin, s. a., [1903.].

17/ Homerova Ilijada. Spjevovi I., II. i VI., preveo Ferdo PAŽUR, Zbirka prijevoda rimskih i grčkih klasika u prozi, svezak 2, Tisak i naklada J. B. Stiflera, Varaždin, s. a., [1903.]. 
18/ Homerova Odiseja. Spjevovi I., II. i IX., preveo Ferdo PAŽUR, Zbirka prijevoda rimskih i grčkih klasika u prozi, svezak 3, Tisak i naklada J. B. Stiflera, Varaždin, s. a., [1903.].

19/ Povijesti rimske Tita Livija od sazdanja grada Rima, knjiga XXI., preveo Ferdo PAŽUR, Zbirka prijevoda rimskih i grčkih klasika u prozi, svezak 4?, Tisak i naklada J. B. Stiflera, Varaždin, s. a., [1903.].

20/ Izabrane pjesme P. Ovidija Nazona, preveo za porabu školsku (IV. i V. gimn. razr.) po knjizi prof. L. Jurmića Ferdo PAŽUR, Zbirka prijevoda rimskih i grčkih klasika u prozi, svezak 11, Tisak i naklada J. B. Stiflera, Varaždin, s. a., [1903.]. 21/ Platonova Apologija i Kriton i ulomak iz Fedona, preveo Ferdo PAŽUR, Zbirka prijevoda rimskih i grčkih klasika u prozi, svezak 6, Tisak i naklada J. B. Stiflera, Varaždin, s. a., [1903.].

22/ Povijest rimskijeh careva K. Tacita. Ljetopisa. Anala, knjiga I., preveo Ferdo PAŽUR, Zbirka prijevoda rimskih i grčkih klasika u prozi, svezak 7, Tisak i naklada J. B. Stiflera, Varaždin, s. a., [1903.].

23/ Povijest rimskijeh careva K. Tacita. Ljetopisa. Anala, knjiga II., preveo Ferdo PAŽUR, Zbirka prijevoda rimskih i grčkih klasika u prozi, svezak 12?, Tisak i naklada J. B. Stiflera, Varaždin, s. a., [1903.].

24/ Kv. Horacija Flaka Izabrane pjesme: školsko izdanje za VIII razred gimnazija, prvo izdanje, preveo Ferdo PAŽUR, Zbirka prijevoda rimskih i grčkih klasika u prozi, Tisak i naklada J. B. Stiflera, Varaždin, s. a., [1904.].

25/ Ciceronov govor za Tita Annija Milona, drugo izdanje?, preveo Ferdo PAŽUR, Tisak i naklada J. B. Stiflera, Varaždin, s. a., [1905.?].

26/ Ciceronovi govori (I-IV) proti L. Katilini: po tekstu školskoga izdanja, preveo Ferdo PAŽUR, Tisak i naklada J. B. Stiflera, Varaždin, s. a., [1906.?].

27/ Kv. Horacija Flaka Izabrane pjesme: školsko izdanje za VIII razred gimnazija, drugo izdanje, preveo Ferdo PAŽUR, Tisak i naklada J. B. Stiflera, Varaždin, s. a., [oko 1906.?].

28/ Povijesti rimske Tita Livija od sazdanja grada izabrane česti, preveo Ferdo PAŽUR, Zbirka prijevoda rimskih i grčkih klasika u prozi, Tisak i naklada J. B. Stiflera, Varaždin, s. a., [1906.].

29/ Ciceronov govor za Tita Annija Milona, preveo Ferdo PAŽUR, Tisak i naklada J. B. Stiflera, Varaždin, s. a., [1907.?].

30/ Povijesti rimske Tita Livija od sazdanja grada Rima, knjige XXI., XXII., svezak II. (knjiga XXII.), preveo Ferdo PAŽUR, Zbirka prijevoda rimskih i grčkih klasika u prozi, Tisak i naklada J. B. Stiflera, Varaždin, s. a., [1907.?]. 
ANA ŠKRILJEVEČKI: Ferdo Pažur (1845. - 1911.). Zaboravljeni varaždinski klasični filolog i prevoditelj

31/ Izabrane pjesme P. Ovidija Nazona, preveo za porabu školsku (IV. i V. gimn. razr.) po knjizi prof. L. Jurmića Ferdo PAŽUR, Zbirka prijevoda rimskih i grčkih klasika u prozi, Tisak i naklada J. B. Stiflera, Varaždin, s. a., [1907.?].

32/ Jugurtinski rat i ulomci iz Historija Gaja Sallustija Krispa, preveo Ferdinard PAŽUR, Zbirka prijevoda rimskih i grčkih klasika u prozi, Tisak i naklada J. B. Stiflera, Varaždin, s. a., [1911.].

33/ Devet govora Demosthenovih, po A. Musiću, preveo V. R., [preveo Ferdo PAŽUR?], Zbirka prijevoda rimskih i grčkih klasika u prozi, Tisak i naklada J. B. Stiflera, Varaždin, s. a., [1912.?].

34/ Lhomond, o slavnijem muževima grada Rima od Romula do Augusta, Tisak i naklada J. B. Stiflera, Varaždin, s. a.

35/ Mali Latinac: vademecum svih pravila latinske slovnice sa svim nepravilnim glagolima, Tisak i naklada J. B. Stiflera, Varaždin, s. a.

\section{b) Izvorna djela}

1/ Ferdo PAŽUR, „O desetercu junačkih naših pjesama“, Izvještaj osiječke gim. god. 1872-3, Osijek, 1873.

2/ Ferdo PAŽUR, Filozofijsko-filologijske razprave (I. O postanku jezika. II. Genetičko-sintaktične misli. III. Čestica (veznik) "da" u hrvatskom jeziku), treći svezak, Knjigotiskarski zavod Platzerova sina, Varaždin, 1886.

3/ Ferdinand PAŽUR, Kurzgefasste praktische Grammatik der kroatischen Sprache für Deutsche: vorzüglich zum Selbstunterrichte für Erwachsene aller Stände, besonders für Kaufleute, Reisende und Gewerbsleute aller Art bestimmt, J. B. Stifler, Varaždin, s. a., [oko 1890.].

4/ Ferdo PAŽUR, Novi čestitar za djecu i školsku mladež: zbirka veoma zgodnih čestitaka svim rodjacima i inim o novojgodini, rodjen-i imendanu u pjesmicama i prozi, Tisak i naklada knjižare J. B. Stiflera, Varaždin, s. a., [1893.?].

\section{IZVORI}

1/ Državni arhiv u Varaždinu, HR-DAVŽ 249. Gimnazija Varaždin. Glavni imenik za školsku godinu 1854./1855.

2/ Državni arhiv u Varaždinu, HR-DAVŽ 249. Gimnazija Varaždin. Glavni imenik za školsku godinu 1861./1862.

3/ Državni arhiv u Varaždinu, HR-DAVŽ 249. Gimnazija Varaždin. Glavni imenik za školsku godinu 1862./1863. 
4/ Državni arhiv u Varaždinu, HR-DAVŽ 249. Gimnazija Varaždin. Glavni imenik za školsku godinu 1869./1870.

5/ Državni arhiv u Varaždinu, HR-DAVŽ 249. Gimnazija Varaždin. Kr. velika gimnazija u Varaždinu. Zapisnici ispita zrelosti od 1854./1855. do 1865./1866. školske godine, zapis za školsku godinu 1861./1862.

6/ Državni arhiv u Varaždinu, HR-DAVŽ 543. Matične knjige rimokatoličkih župa. Matica rođenih župe svetog Vida Varaždin (1831. - 1848.), zapis za 1845. godinu.

7/ Gradska knjižnica i čitaonica „Metel Ožegović“ Varaždin. Zavičajna zbirka, sign. 371(091)IZVESTJE 1870. Izvestje kraljevske gymnazije varaždinske koncem školske godine 1870., Brzotiskom Platzera i sina, Varaždin, 1870.

8/ Gradska knjižnica i čitaonica "Metel Ožegović" Varaždin. Zavičajna zbirka, sign. 371(091)IZVJG 1932. Krešimir FILIĆ, „Knjižnica varaždinske gimnazije“, Godišnji izvještaj državne realne gimnazije u Varaždinu 1932 - 33, Tisak Stiflerove tiskare, Varaždin, 1933., 5-16.

9/ Gradska knjižnica i čitaonica "Metel Ožegović“ Varaždin. Zavičajna zbirka, sign. 938 DEMOS dev. Devet govora Demosthenovih, po A. Musiću, preveo V. R., Zbirka prijevoda rimskih i grčkih klasika u prozi, Tisak i naklada J. B. Stiflera, Varaždin, s. a.

10/ Gradska knjižnica i čitaonica „Metel Ožegović“ Varaždin. Zavičajna zbirka, sign. 811.124 MALI. Mali Latinac: vademecum svih pravila latinske slovnice sa svim nepravilnim glagolima, Tisak i naklada J. B. Stiflera, Varaždin, s. a.

11/ Gradska knjižnica i čitaonica "Metel Ožegović" Varaždin. Zavičajna zbirka, sign. 808.62 PAŽUR fil. Ferdo PAŽUR, Filozofijsko-filologijske razprave (I. O postanku jezika. II. Genetičko-sintaktične misli. III. Čestica (veznik) "da“ u hrvatskom jeziku), treći svezak, Knjigotiskarski zavod Platzerova sina, Varaždin, 1886.

12/ Gradska knjižnica i čitaonica "Metel Ožegović" Varaždin. Zavičajna zbirka, sign. 811.163.42 PAŽK. Ferdinand PAŽUR, Kurzgefasste praktische Grammatik der kroatischen Sprache für Deutsche: vorzüglich zum Selbstunterrichte für Erwachsene aller Stände, besonders für Kaufleute, Reisende und Gewerbsleute aller Art bestimmt, J. B. Stifler, Varaždin, [oko 1890.].

13/ Gradska knjižnica i čitaonica "Metel Ožegović“ Varaždin. Zavičajna zbirka, sign. 82.0 PAŽUR PUČ. Zvonimir PUŽAR [i. e.] Ferdo PAŽUR, Pučki listar: sbirka svakovrstnih pismenih sastavaka za sve prigode u domaćem, družtvenom $i$ poslovnom životu, Tisak i naklada J. B. Stiflera, Varaždin, s. a.

14/ Gradski muzej Varaždin, inv. br. GMV 88100. Gimnazijalna svedočba Ferde Pažura za prvo polugodište školske godine 1861./1862. 
ANA ŠKRILJEVEČKI: Ferdo Pažur (1845. - 1911.). Zaboravljeni varaždinski klasični filolog i prevoditelj

15/ Gradski muzej Varaždin, inv. br. GMV KPO 7984. „Moja posljednja volja“, oporuka Ferde Pažura, 1897., str. 1-26.

16/ Gradski muzej Varaždin, inv. br. GMV KPO 7985. Liječnička svjedodžba Ferde Pažura, Javna obća bolnica braće milosrdne, Zagreb, 7. svibnja 1878.

17/ Gradski muzej Varaždin, inv. br. GMV KPO 7986. Liječnička svjedodžba Ferde Pažura, Varaždin, 4. listopada 1878.

18/ Knjižnica Uršulinskog samostana Varaždin, sign. Cd-V-251. Ferdo PAŽUR, Novi čestitar za djecu i školsku mladež: zbirka veoma zgodnih čestitaka svim rodjacima i inim o novoj godini, rodjen- i imendanu u pjesmicama i prozi, Tisak i naklada knjižare J. B. Stiflera, Varaždin, s. a.

19/ Novine digitalizirane na portalu Novinstvo Varaždina (URL: http://library. foi.hr/nv/): Hrvatska pošta, god. 1898./br. 14 i 34; Hrvatske pravice, god. 1907./br. 30, god. 1911./br. 16 i 17; Hrvatska straža, god. 1886./br. 33; Naše pravice, god. 1911./br. 17; Pučki prijatelj, god. 1870./br. 10 i 42; Varaždinske vijesti, god. 1961./br. 814, god. 1985./br. 8, god. 1996./br. 19.

20/ Novine digitalizirane na portalu Stare hrvatske novine (URL: http://dnc. nsk.hr/Newspapers/), Nacionalna i sveučilišna knjižnica u Zagrebu, 2009.: Sriemski Hrvat, god. 1886./br. 56; Narodne novine, god. 1888./br. 47.

21/ Prva gimnazija Varaždin, digitalizirana građa (URL: https://library.foi.hr/zbirke/ gimnazija-vz/). Izvestje kraljevske gimnazije varaždinske koncem školske godine 1870./1871., Brzotiskom Platzera i sina u Varaždinu, Varaždin, 1871.

22/ Prva gimnazija Varaždin, digitalizirana građa. Izvjestje kraljevskoga gimnazija varaždinskoga koncem školske godine 1871./1872., Berzotiskom Platzera i sina u Varaždinu, Varaždin, 1872.

23/ Prva gimnazija Varaždin, digitalizirana građa. Izvješće kralj. velike gimnazije u Varaždinu koncem školske godine 1884./1885. , Tiskarski zavod Platzera sina, Varaždin, 1885.

24/ Prva gimnazija Varaždin, digitalizirana građa. Izvješće kralj. velike gimnazije u Varaždinu koncem školske godine 1886./1887., Tiskarski zavod Platzera sina, Varaždin, 1887.

25/ Prva gimnazija Varaždin, digitalizirana građa. Izvještaj kr. velike gimnazije u Varaždinu za školsku godinu 1905. - 6., Knjigotiskara J. B. Stiflera, Varaždin, 1906.

26/ Prva gimnazija Varaždin, digitalizirana građa. Izvještaj kralj. velike gimnazije u Varaždinu za školsku godinu 1907. - 1908., Tiskara Stjepana pl. Platzera, Varaždin, 1908.

27/ Prva gimnazija Varaždin, digitalizirana građa. Program kraljevske gimnazije u Varaždinu koncem školske godine 1864., Brzotiskom narodne tiskarnice Dra. Ljudevita Gaja, Zagreb, 1864. 


\section{LITERATURA}

1/ Antun CUVAJ, Građa za povijest školstva kraljevina Hrvatske i Slavonije od najstarijih vremena do danas, svezak IV.: Od 31. prosinca 1851. do 20. listopada 1860., drugo ispravljeno i popunjeno izdanje, Trošak i naklada Kr. hrv. slav. dalm. zem. vlade, Odjela za bogoštovlje i nastavu, Zagreb, 1910.

2/ Antun CUVAJ, Građa za povijest školstva kraljevina Hrvatske i Slavonije od najstarijih vremena do danas, svezak V.: Od 20. listopada 1860. do 20. travnja 1868., drugo ispravljeno i popunjeno izdanje, Trošak i naklada Kr. hrv. slav. dalm. zem. vlade, Odjela za bogoštovlje i nastavu, Zagreb, 1910.

3/ Antun CUVAJ, Građa za povijest školstva kraljevina Hrvatske i Slavonije od najstarijih vremena do danas, svezak X.: Od 31. listopada 1888. do danas, drugo ispravljeno i popunjeno izdanje, Trošak i naklada Kr. hrv. slav. dalm. zem. vlade, Odjela za bogoštovlje i nastavu, Zagreb, 1913.

4/ Ernest FIŠER, "Varaždin kao rasadište hrvatskih književnih povjesničara“, Zbornik o Branku Vodniku: književnom povjesničaru, Zbornik radova sa znanstvenog skupa Zagreb - Varaždin, 13. - 15. travnja 2000., glavni urednik Tihomil MAŠTROVIĆ, Hrvatski studiji Sveučilišta u Zagrebu, Zagreb, 2001., 417-424.

5/ Ivo FRANGEŠ, Nove stilističke studije, Globus, Zagreb, 1986.

6/ Luka GOLUB, "Iz mojih uspomena (Doba od 1894-1902)", Spomenica Varaždinske gimnazije: 1636 - 1936, uredio Krešimir FILIĆ, Tiskara Slobodine „Narodne tiskare“, Varaždin, 1937., 124-137.

7/ Rudolf HORVAT, Povijest grada Varaždina, Hrvatska akademija znanosti i umjetnosti, Zavod za znanstveni rad u Varaždinu, Grad Varaždin, Varaždin, 1993.

8/ Siniša HORVAT, „Krešimir Filić - djelatnik u Varaždinskoj Gimnazijskoj ekstenzi", Radovi Zavoda za znanstveni rad Varaždin, br. 23, Hrvatska akademija znanosti i umjetnosti, Zavod za znanstveni rad Varaždin, Zagreb Varaždin, 2012., 129-156.

9/ Ivan KAMPUŠ et al., Sveta Marija na Dolcu: mala monografija župe, redaktor Juraj LONČAREVIĆ, Župni ured sv. Marije - Kršćanska sadašnjost, Zagreb, 1985.

10/ Mira KOLAR-DIMITRIJEVIĆ, „Pučki pisac Zvonimir Pužar i Križevci 1910. - 1923.“, Cris: časopis Povijesnog društva Križevci V/1, Povijesno društvo Križevci, Križevci, 2003., 16-26. URL: https://hrcak.srce.hr/93702 (Datum pristupa: 1. kolovoza 2020.). 
ANA ŠKRILJEVEČKI: Ferdo Pažur (1845. - 1911.). Zaboravljeni varaždinski klasični filolog i prevoditelj

11/ Marijan KRAŠ, „'Varasdiniensia' - zavičajna zbirka Gradske knjižnice i čitaonice 'Sloboda', Varaždin“, Vjesnik bibliotekara Hrvatske, 17/1971., glavni i odgovorni urednik Branko HANŽ, Hrvatsko bibliotekarsko društvo, Zagreb, 1971., 100-103.

12/ Magdalena LONČARIĆ, Tiskarstvo u Varaždinu 1586. - 1946., katalog izložbe, TIVA Tiskara Varaždin - Gradski muzej Varaždin, Varaždin, 2007.

13/ Ivan MILČETIĆ, „Ferdo Pažur (nekrolog)“, Savremenik: mjesečnik Društva hrvatskih književnika, godina VI., urednik dr. Branimir VIZNER-LIVADIĆ, Društvo hrvatskih književnika, Zagreb, 1911., 377-378.

14/ Stjepan PARMAČEVIĆ, „Uz tristagodišnjicu varažd. gimnazije“, Spomenica Varaždinske gimnazije: 1636 - 1936, uredio Krešimir FILIĆ, Tiskara Slobodine „Narodne tiskare“, Varaždin, 1937., 26-43.

15/ Bosiljka PASKA, „Pažur, Ferdo“, Gimnazija - SC „Gabrijel Santo“ 1636. 1986., glavni i odgovorni urednik Josip RUNJAK, Savjet SC „Gabrijel Santo“, Varaždin, 1986., 328-329.

16/ Gustav PIASEK i Martina PIASEK, „Tradicija hospitala (ksenodohija) u Varaždinu“, Arhiv za higijenu rada i toksikologiju 57, br. 4, Institut za medicinska istraživanja i medicinu rada, Zagreb, 2006., 459-468. URL: https://hrcak.srce.hr/6051 (Datum pristupa: 20. srpnja 2020.).

17/ Marko SAMARDŽlJA, „Vatroslav Rožić. Predgovor", Jezikoslovne rasprave $i$ članci, Franjo IVEKOVIĆ et al.; priredio Marko SAMARDŽIJA, Matica hrvatska, Zagreb, 2001., 227-236.

18/ Petar ŠEGEDIN, „Prijevodi Platonovih djela na hrvatski jezik“, Prilozi za istraživanje hrvatske filozofske baštine 29., br. 1-2 (57-58), Institut za filozofiju, Zagreb, 2003., 387-411. URL: https://hrcak.srce.hr/68585 (Datum pristupa: 29. srpnja 2020.).

19/ Zlatko ŠEŠELJ, „Bibliografija prijevoda klasične grčke i rimske književnosti u knjigama i zbirnim izdanjima 1900-1918.", Latina et Graeca, vol. 1, br. 15, Latina et Graeca, Institut za klasične jezike i antičku civilizaciju, Zagreb, 1980., 69-97. URL: https://hrcak.srce.hr/223472 (Datum pristupa: 28. srpnja 2020.).

20/ Spomenka TEŽAK, kataloške jedinice u: Gimnazijskih 380 godina, katalog izložbe, Prva gimnazija Varaždin, Varaždin, 2016., 41.

21/ Luka ZIMA, „Nacrt naše metrike narodne: obzirom na stihove drugih naroda a osobito Slovenâ", Rad Jugoslavenske akademije znanosti i umjetnosti, knjiga 48, Jugoslavenska akademija znanosti i umjetnosti, Zagreb, 1879., 170-221. 


\section{INTERNETSKE STRANICE}

1/ Hrvatski nacionalni skupni katalog. URL: http://skupnikatalog.nsk.hr/ (Datum pristupa: 4. kolovoza 2020.).

2/ Knjižnica Uršulinskog samostana Varaždin. Katalog. URL: https://bit. ly/3h6YSXW (Datum pristupa: 11. kolovoza 2020.).

3/ Nacionalna i sveučilišna knjižnica u Zagrebu, 2020., Katalog. URL: http:// katalog.nsk.hr/ (Datum pristupa: 4. kolovoza 2020.).

4) Warasdiniensia-Digitalizirana zavičajna zbirka Gradske knjižnice i čitaonice „Metel Ožegović" Varaždin. URL: https://library.foi.hr/zbirke/varazdin/ (Datum pristupa: 4. kolovoza 2020.).

\section{SUMMARY}

\section{FERDO PAŽUR (1845 - 1911). VARAŽDIN'S FORGOTTEN CLASSICAL PHILOLOGIST AND TRANSLATOR}

Ferdo Pažur is a classical philologist, translator and writer from Varaždin. He attended the Varaždin Gymnasium and graduated in 1862 as the best student in the class. He worked at the same institution as a trainee teacher. He was teaching different subjects; Latin, Croatian, German and Geography. He continued his education at the University of Vienna where he was among the best students of classical philology. After returning to his homeland he worked at the Varaždin, Požega and Osijek high schools. Due to his alcohol addiction he became mentally ill. He lived by translating, writing and giving instructions. He spent his last days in almshouse (hospice) in Varaždin where he died. He was buried in the Varaždin cemetery. Ferdo Pažur left an abundant opus composed of translations and original works. There are more than thirty titles of Pažur's translations. He mostly translated works of classical Greek and Roman authors which were used in schools. That brought him popularity abroad. Pažur wrote four original works which testify to the writer's deep knowledge of the Croatian language and his love for the Croatian written word. Although forgotten, thanks to his rich work Ferdo Pažur occupies a significant place among Varaždin translators and linguists.

Key Words: Ferdo Pažur; Varaždin; Varaždin Gymnasium; classical philology; Croatian language; translations. 
ANA ŠKRILJEVEČKI: Ferdo Pažur (1845. - 1911.). Zaboravljeni varaždinski klasični filolog i prevoditelj

\section{PRILOZI}

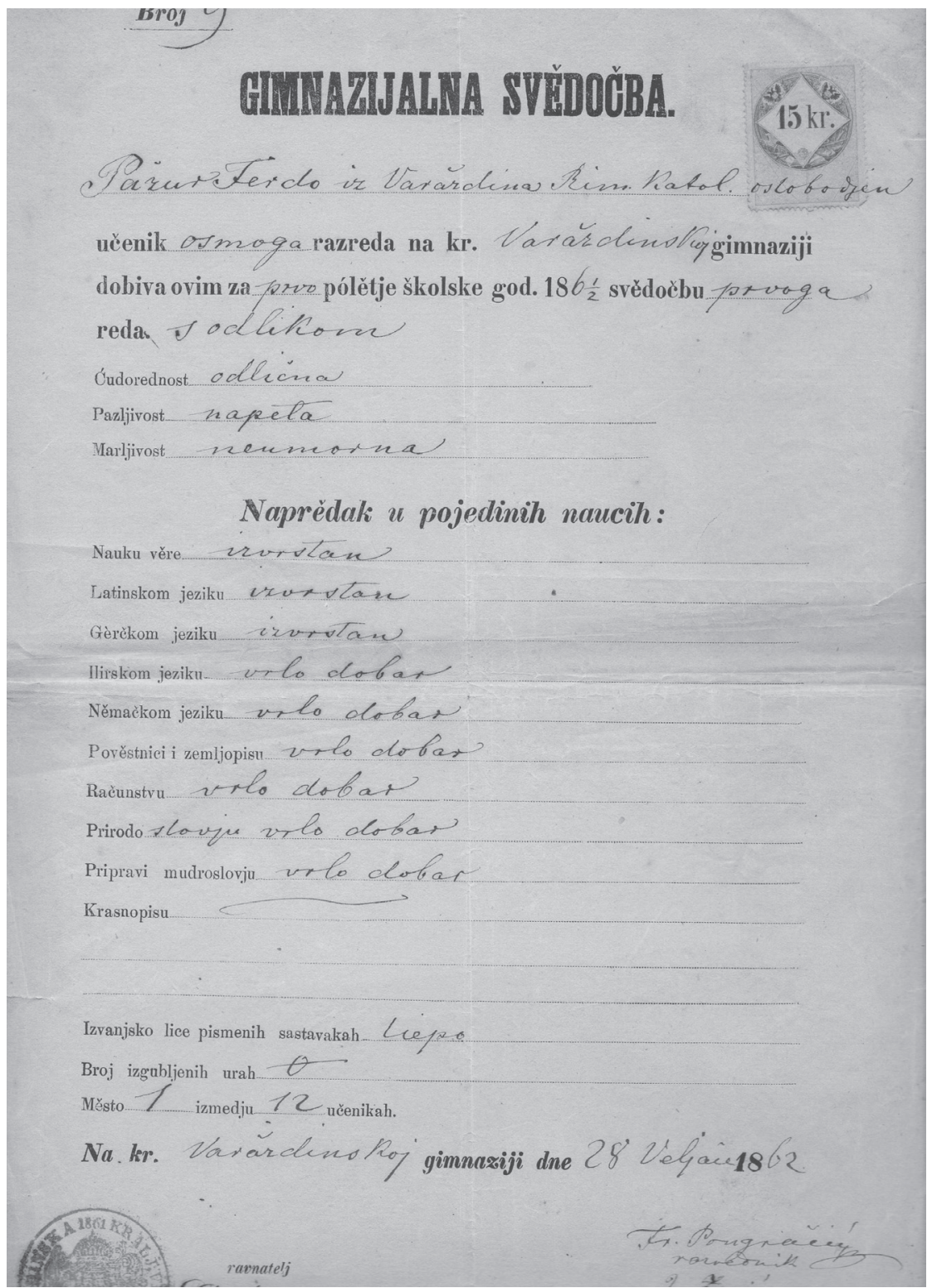

Slika 1. Gimnazijalna svedočba Ferde Pažura za prvo polugodište školske godine 1861./1862. (Gradski muzej Varaždin. GMV 88100) 


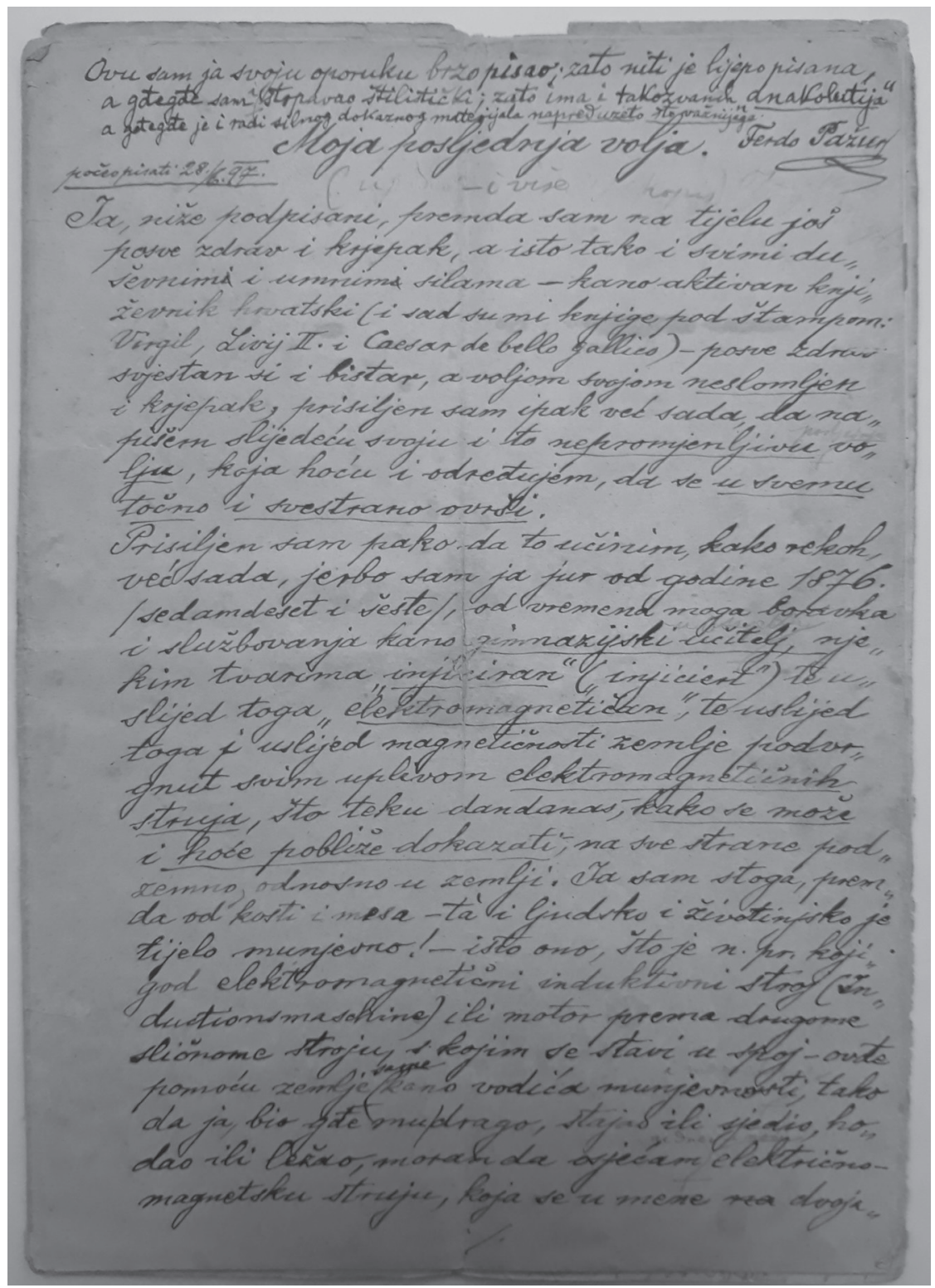

Slika 2. „Moja posljednja volja“, oporuka Ferde Pažura, 1897.

(Gradski muzej Varaždin. GMV KPO 7984) 
ANA ŠKRILJEVEČKI: Ferdo Pažur (1845. - 1911.). Zaboravljeni varaždinski klasični filolog i prevoditelj

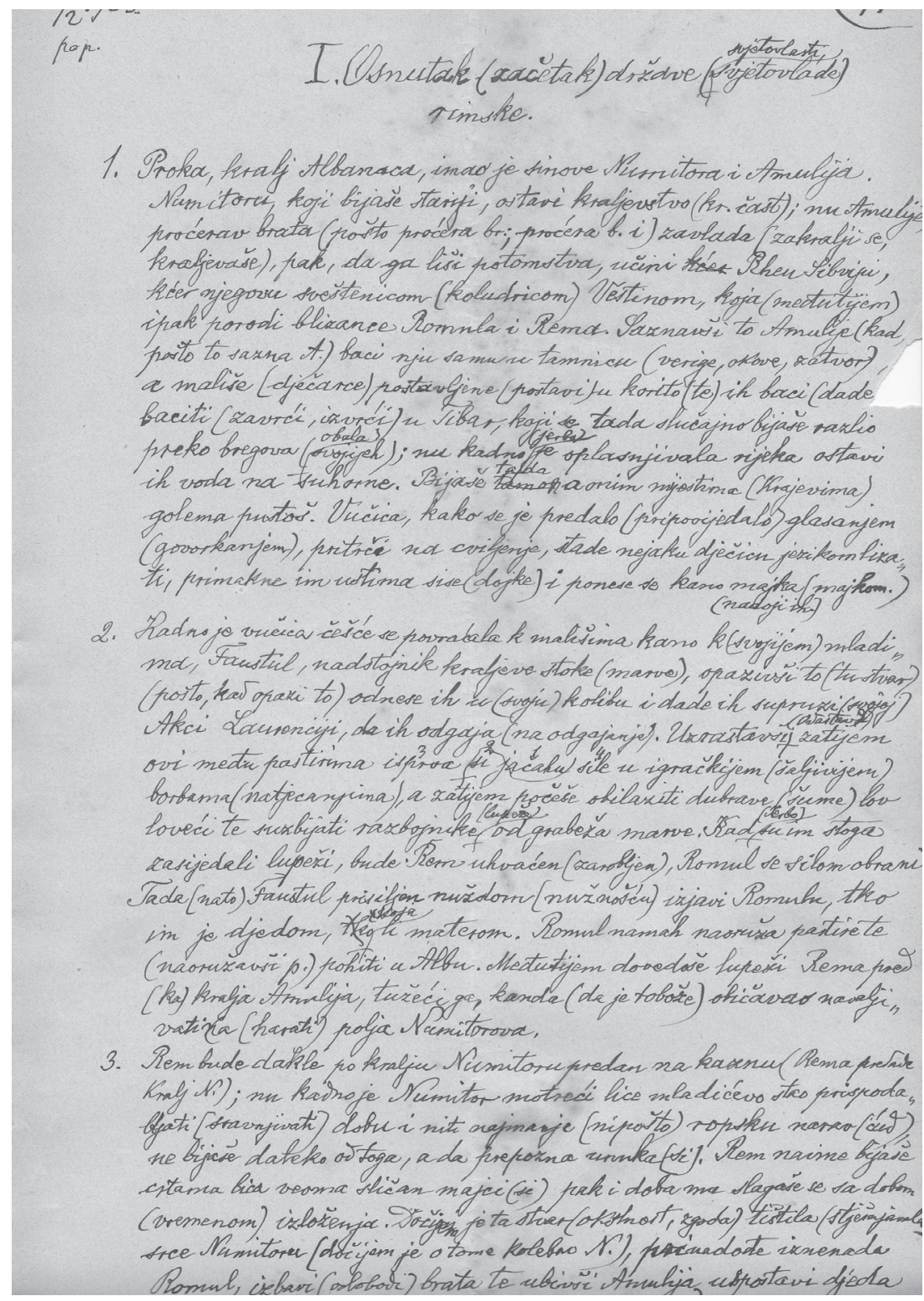

Slika 3. Rukopis Ferde Pažura, 1903.

(Gradski muzej Varaždin. GMV 90454) 


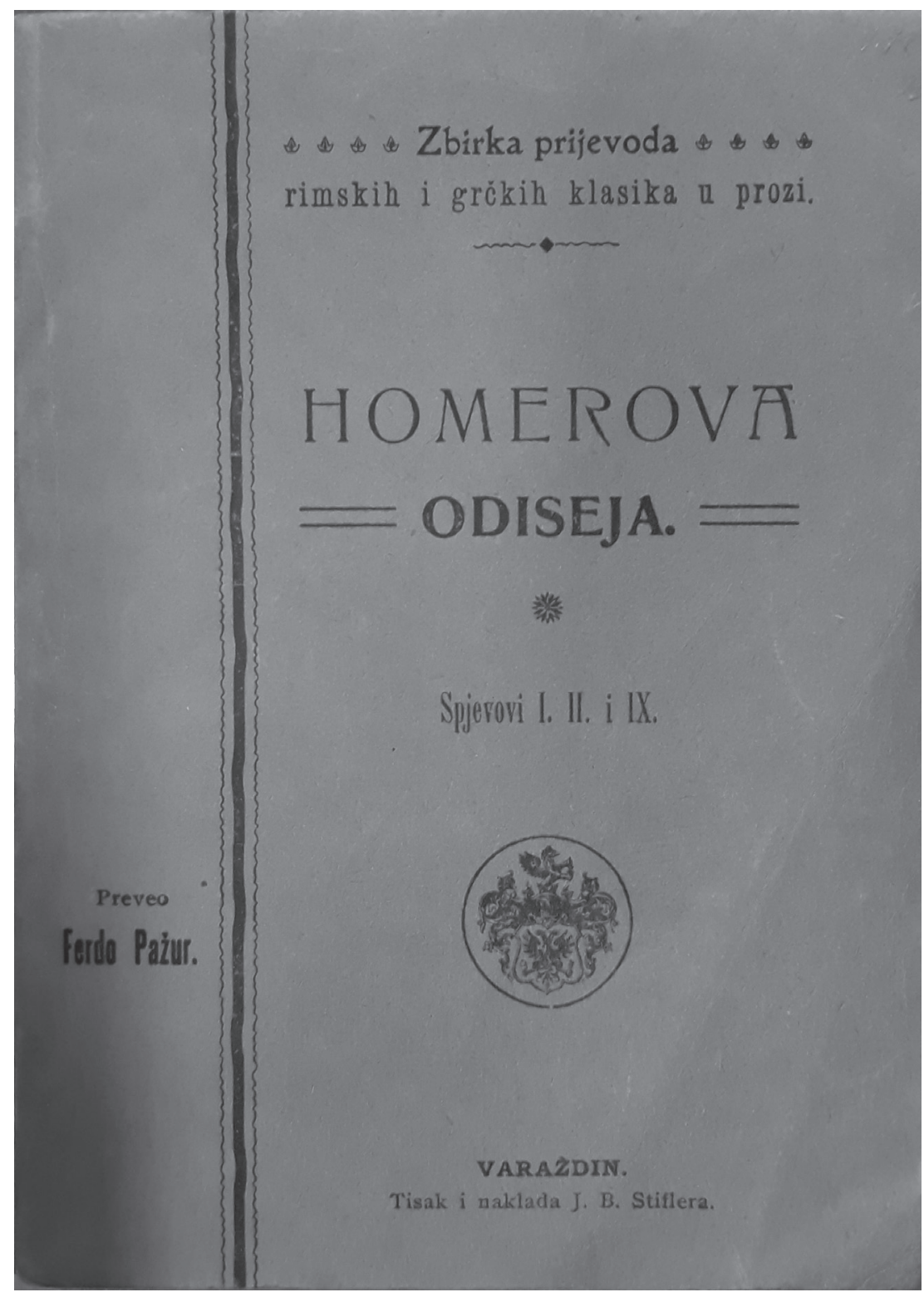

Slika 4. Homerova Odiseja. Preveo Ferdo Pažur. (Gradska knjižnica i čitaonica „Metel Ožegović“ Varaždin) 
ANA ŠKRILJEVEČKI: Ferdo Pažur (1845. - 1911.). Zaboravljeni varaždinski klasični filolog i prevoditelj

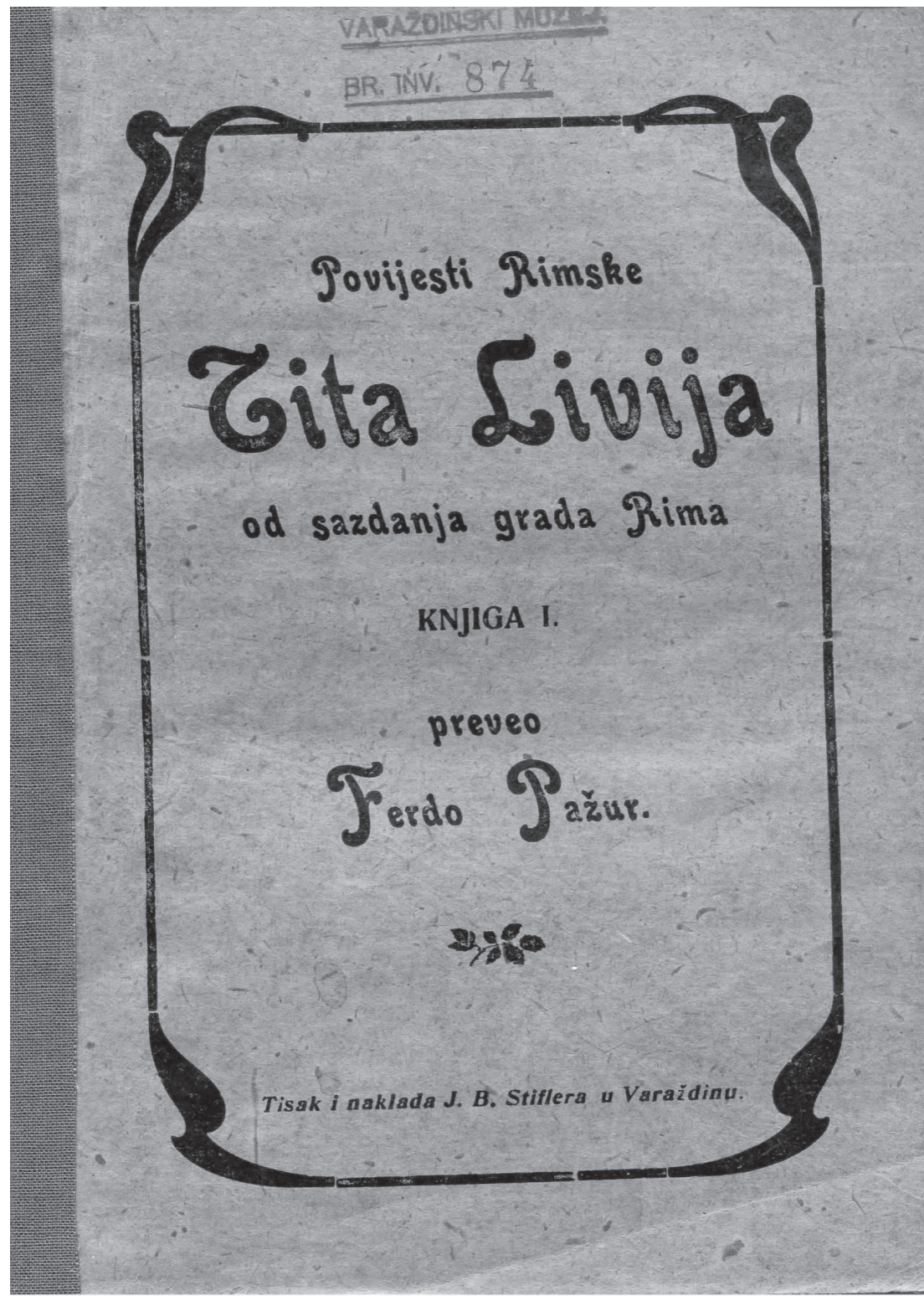

Slika 5. Povijesti Rimske Tita Livija od sazdanja grada Rima. Preveo Ferdo Pažur. (Gradska knjižnica i čitaonica „Metel Ožegović“ Varaždin) 

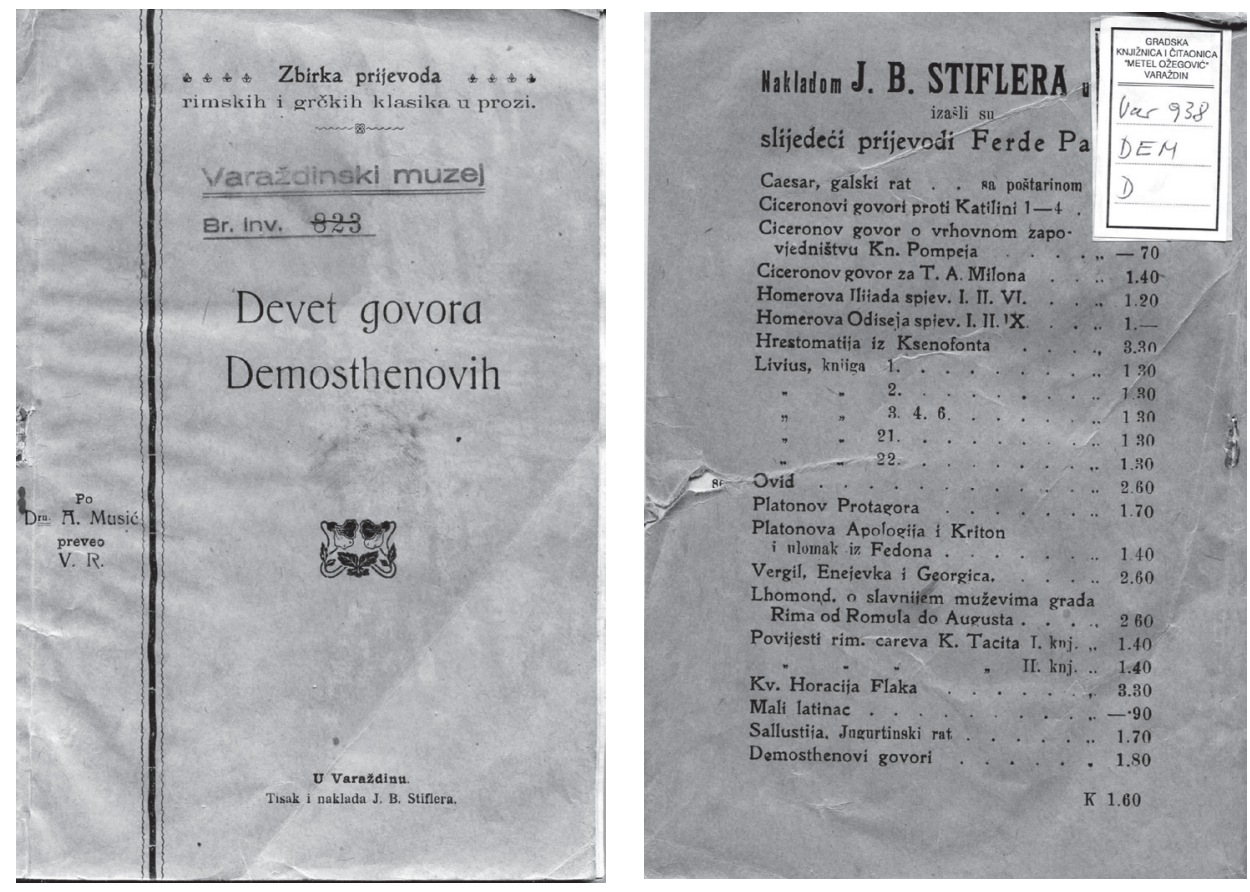

Slika 6. Prednje i stražnje korice Devet govora Demosthenovih.

(Gradska knjižnica i čitaonica „Metel Ožegović“ Varaždin) 
ANA ŠKRILJEVEČKI: Ferdo Pažur (1845. - 1911.). Zaboravljeni varaždinski klasični filolog i prevoditelj
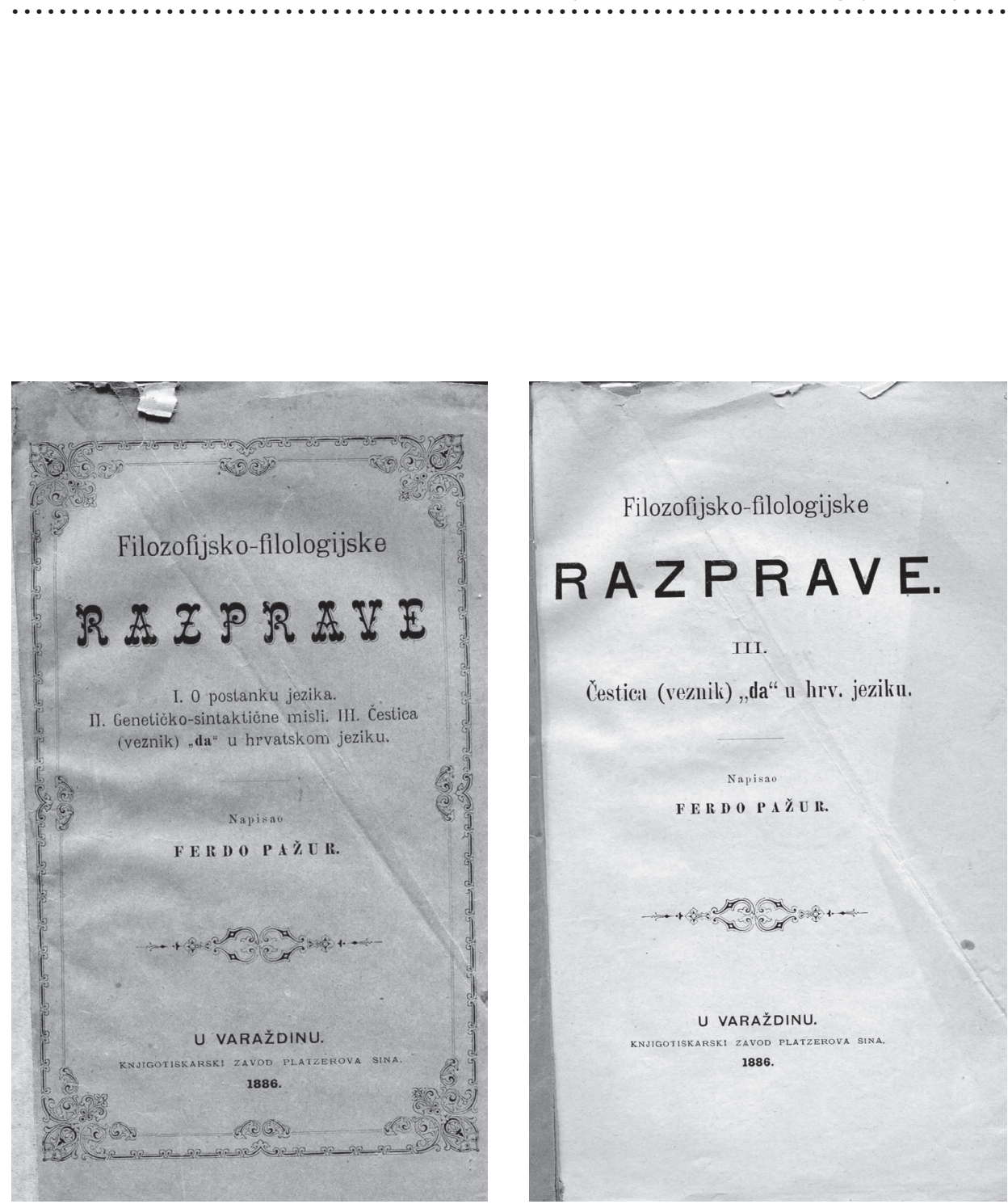

Slika 7. Filozofijsko-filologijske razprave. Napisao Ferdo Pažur. (Gradska knjižnica i čitaonica „Metel Ožegović“ Varaždin) 


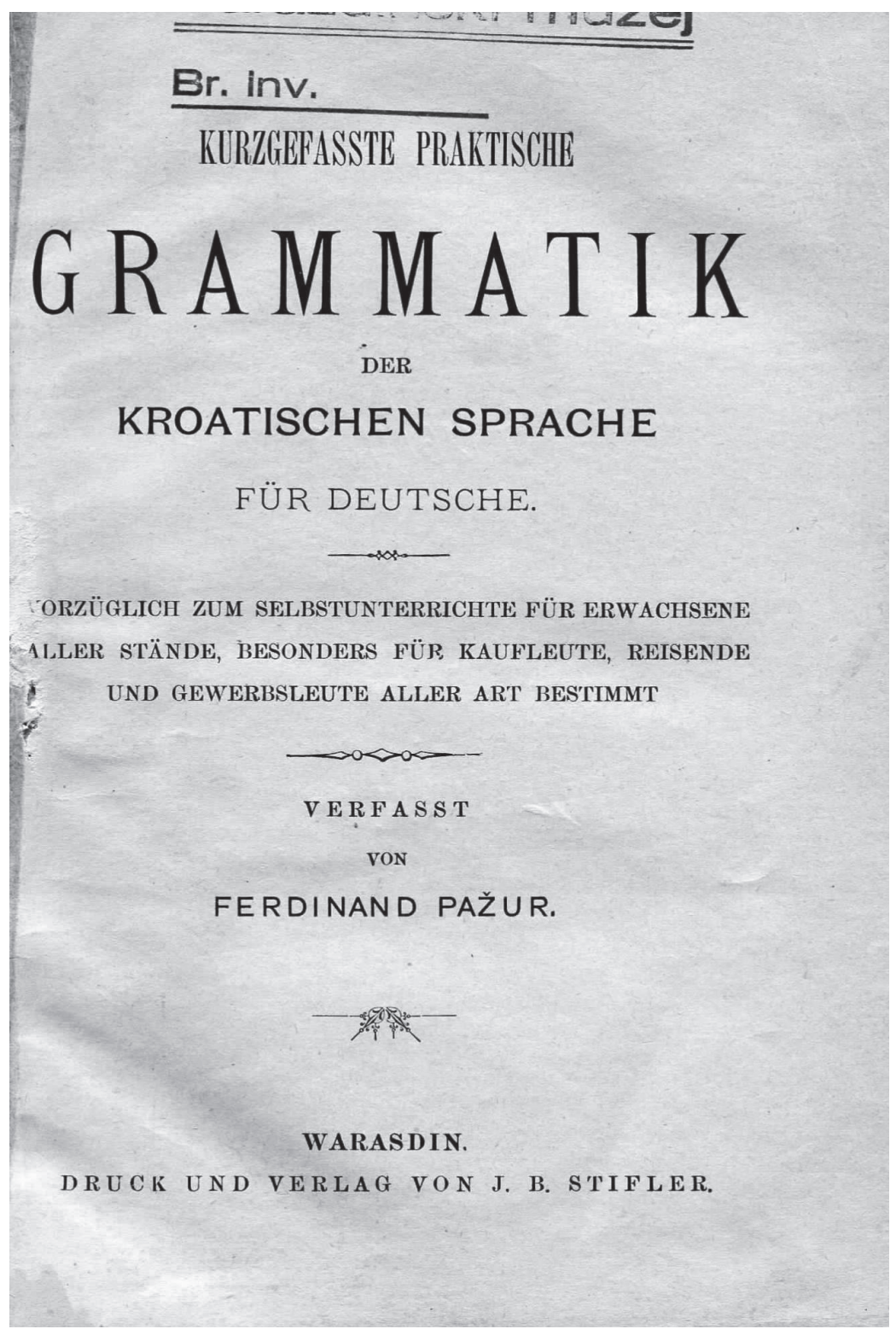

Slika 8. Kurzgefasste praktische Grammatik der kroatischen Sprache für Deutsche. Sastavio Ferdinand Pažur. (Gradska knjižnica i čitaonica „Metel Ožegović“ Varaždin) 
ANA ŠKRILJEVEČKI: Ferdo Pažur (1845. - 1911.). Zaboravljeni varaždinski klasični filolog i prevoditelj

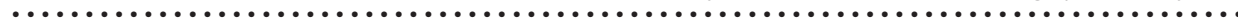

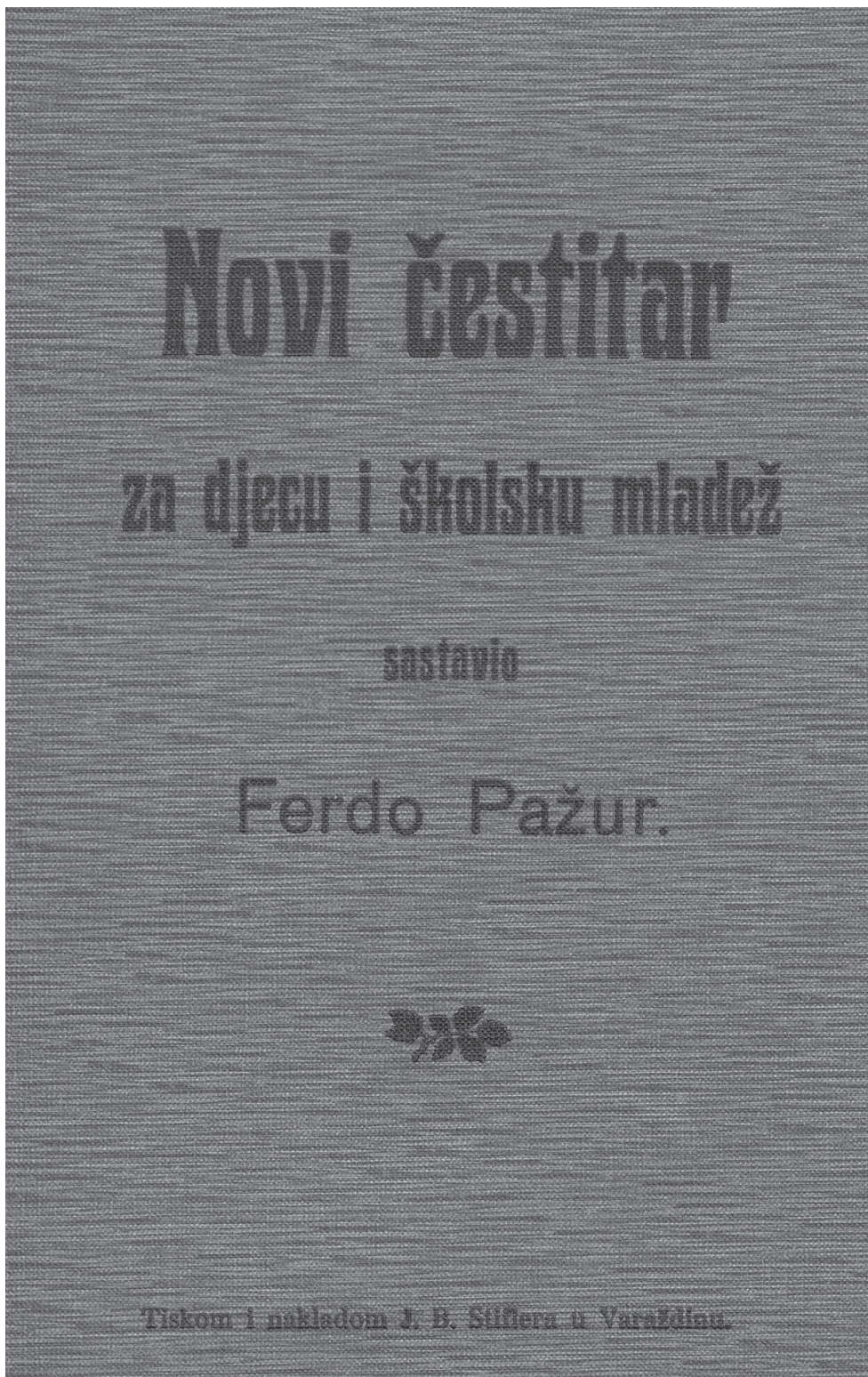

Slika 9. Novi čestitar za djecu i školsku mladež. Sastavio Ferdo Pažur. (Knjižnica Uršulinskog samostana Varaždin) 